Krabbendam \& Leslie: Traligill Transverse Zone

Geological Society, London, Special Publications 335

Continental Tectonics and Mountain Building: the legacy of Peach and Horne

\title{
Lateral variations and linkages in thrust geometry: the Traligill Transverse Zone, Assynt Culmination, Moine Thrust Belt, NW Scotland
}

\author{
M KRABBENDAM \& A G LESLIE \\ British Geological Survey, \\ Murchison House, West Mains Road, Edinburgh EH9 3LA, UK \\ Corresponding author:mkrab@bgs.ac.uk
}

\begin{abstract}
Abrupt lateral changes in thrust geometry occur in many fold-and-thrust belts along so-called transverse zones, commonly related to pre-existing basement faults. However, the causative structures are usually concealed. We analyse here the Traligill Transverse Zone in the Assynt Culmination of the Caledonian Moine Thrust Belt, NW Scotland. This transverse zone trends sub-parallel to the WNW transport direction and is associated with en echelon faults cutting thrusts, discontinuity of thrust architecture and oblique fold-and-thrust structures. Thick thrust sheets north of the Transverse Zone contain thick basement slices; thrust sheets to the south are thin and involve a thin-bedded sequence. The Traligill Transverse Zone developed above the Loch Assynt Fault, a basement cross-fault, , and reactivated Proterozoic ductile shearzone. Piercing point analysis shows that the cross-fault was active both before and after thrusting. Thrusting thus affected strata that were already disrupted by steep faults. The amplitude of the disturbance in fold-and-thrust architecture along the Traligill Transverse Zone is much greater than the vertical displacement along the fault; this is attributed to localised transpressional thruststacking. Other basement cross-faults and their relationship with lateral variations within the Moine Thrust Belt and in other thrust belts are discussed.

(end of Abstract)
\end{abstract}


Fold-and-thrust belts are intensely studied features of mountain belts around the world; countless papers have reported on their geometry, kinematics, mechanics and petroleum potential (McClay 1992; 2004 and references therein). Many studies have dealt with palinspastic reconstructions and balanced cross-sections parallel to the thrust transport direction; far fewer have focussed on the 3$\mathrm{D}$ architecture of fold-and-thrust belts, and how lateral variations in thrust architecture in different segments of a thrust belt are linked via so-called transverse zones (e.g. Mitra 1988; Thomas 1990; Fermor, 1999; Paulsen and Marshak; Bégin and Spratt 2002). This relative paucity in research is, in part, a consequence of the difficulty in obtaining rigorous constraint upon the 3-D geological

model. In recent years, exploration in both off-shore and onshore thrust belts has generated 3-D seismic data sets and enabled 3-D visualisation and interpretation of thrust geometries (e.g. Hinsch et al. 2002; Gorney et al. 2007). Seismic data are, however, by their nature relatively lowresolution and it is advantageous to compare and contrast seismically constrained models with well-exposed on-shore analogues.

The authors have revised the classic geological map, the "Assynt Special Sheet" (Geological Survey of Great Britain 1923; British Geological Survey 2007), in the Moine Thrust Belt in the Caledonides of NW Scotland. In this paper we describe an abrupt lateral change in thrust architecture that occurs across the Traligill Transverse Zone (TTZ). The TTZ transects the Assynt Culmination (Figs. 1, 2), the largest and one of the most spectacular and historically significant of all the culminations in the Moine Thrust Belt. In contrast to other studies on transverse zones (e.g. Mitra 1988; Paulsen and Marshak 1999; Bégin and Spratt 2002), the displacement evolution on cross-faults associated with the TTZ in Assynt can be accurately determined using well-constrained piercing points, both within the Moine Thrust Belt and in its foreland. We will show how displacements across normal faults oriented sub-parallel to the subsequent thrust direction can create small steps in the pre-thrust template, but that such small steps can cause large-scale complexities within the thrust belt.

\section{Geological Setting}

The Moine Thrust Belt (Fig. 1) is among the best exposed and studied fold-and-thrust belts in the world, and dominates the geological structure of the NW Highlands of Scotland. The belt developed during the Scandian (Silurian) phase of the Caledonian Orogeny (e.g. van Breemen et al. 1979; Freeman et al. 1998; Dallmeyer et al. 2001; Strachan et al. 2002). The roof of the Moine Thrust Belt is defined by the Moine Thrust, a structure which carries the Neoproterozoic Moine Supergroup in its hanging wall. These Moine rocks are dissected and repeated by a number of ductile thrusts (Barr et al. 1986) and are arranged within a regional-scale structure that, like the Moine Thrust Belt structurally below, incorporates culminations and abrupt lateral variations (Leslie et al. this volume). In the footwall of the Moine Thrust, the Moine Thrust Belt consists of a series of thrust sheets that transport rocks that can be confidently correlated with the foreland.

The Moine Thrust Belt has been studied for over 150 years, largely because it contains a great variety of well-exposed thrust geometries,. In some places the Moine Thrust Belt is a single, simple thrust plane; elsewhere thrust sheets are piled on top of each other in wild and glorious complexity (e.g. Elliot \& Johnson 1980, Butler 1982, 1984, Butler et al. 2007; Butler this volume; Coward 1982, 1983, 1985). Thrust sheets vary in thickness from km-scale to less than $10 \mathrm{~m}$ and a wide range of different thrust geometries are present. These include foreland and hinterland dipping-duplexes (e.g. Breabag Dome, Dundonnel), anticlinal stacks, thrust nappes, 
true fold-nappes (Lochalsh) and lateral ramps. In some places the thrust belt consists of a single thrust (eg. at Knockan Crag), in other places thrusting is thin-skinned (eg. near Eriboll; south and western part of Assynt culmination), whilst elsewhere thrusting was relatively thick-skinned (eg near Achnashellach and near Kishorn). Variability along an east-west cross-section (along the thrust direction) can be readily explained by the very different rheological properties of the lithologies involved in the thrust belt. These lithologies range from massive Lewisian Gneiss basement, thick-bedded Torridon Sandstone, to thin incompetent dolomitic siltstone layers sandwiched between Cambro-Ordovician dolostone and Cambrian quartz-arenite (Fig. 3). However, the Cambro-Ordovician cover strata are characterised by a remarkable lateral uniformity in thickness and lithology, with all units (some less than $10 \mathrm{~m}$ thick) continuously present along a strike length of c. $200 \mathrm{~km}$ (eg. Peach et al. 1907, p. 364, Prigmore \& Rushton 1999). This begs the question why there is such a strong lateral (i.e. along strike) variability in kinematics and architecture, within the thrust belt.

\section{Lithologies in the Moine Thrust Belt and its environs}

In the Foreland west of the Moine Thrust Belt the oldest rocks are in the Lewisian Gneiss Complex, and comprise felsic to intermediate Archaean orthogneisses (Scourian Gneiss), intruded by the Early Palaeoproterozoic mafic and ultramafic Scourie Dyke Swarm (Park et al. 2002). The complex is unconformably overlain by the early-Neoproterozoic Torridon Group which consists of several kilometres of coarse red arkosic cross-bedded sandstone (Applecross Formation). Heterolithic units of conglomerate, breccia, sandstone and mudstone of the Diabaig Formation are locally present beneath the Applecross Formation (Stewart 2002).

Another major unconformity separates the Torridon Group from the overlying CambroOrdovician sequence (Fig. 3). The lower part of this sequence (Ardvreck Group) is dominated by the Eriboll Formation, comprising the arenitic Basal Quartzite and Pipe Rock members (each 75 $100 \mathrm{~m}$ thick); the latter is characterised by abundant Skolithos 'pipes'; these distinctive trace fossils form ideal strain markers (Wilkinson et al. 1975; Coward \& Kim, 1981). The much thinner An t-Sron Formation comprises dolomitic siltstone and dolostone of the Fucoid Beds Member (10 - $20 \mathrm{~m}$ thick), succeeded everywhere by coarse quartz arenite of the Salterella Grit Member (c. 7 m thick). The siliciclastic Ardvreck Group is succeeded by the calcareous Durness Group, of which only the three lowest Formations occur in Assynt. The lower Ghrudaidh Formation (c. $65 \mathrm{~m}$ thick) comprises dark grey dolostones; these are succeeded everywhere by pale grey dolostones of the Eilean Dubh Formation (c. 120 m thick). Only small occurrences of the still younger Sailmhor Formation occur in Assynt; these dolostones are characterized by abundant chert concretions and distinctive burrow-mottling. Park et al. (2002), Wright and Knight (1995), McKie (1991); Prigmore \& Rushton (1999) and Armstrong et al. (2006) provide detailed descriptions of the Cambro-Ordovician sequence; relevant here is that the sub-Cambrian unconformity is a remarkably planar surface and that the Cambro-Ordovician formations record an extremely uniform stratigraphical thickness along the length of the Moine Thrust Belt, very much a 'layer-cake' (the thickness variations shown above are along $200 \mathrm{~km}$ strike length, from Durness to Skye, Fig. 1).

The Moine Supergroup, of which only the lowermost Morar Group is relevant here, is always separated from the other lithologies by the Moine Thrust. The Morar Group comprises a thick sequence of arkosic to sub-arkosic psammites with subsidiary pelite and semipelite of fluvial 
origin; all are of broadly similar age and origin as the Torridon Group of the Foreland, with which they have been correlated (Krabbendam et al. 2008).

Two plutons and several swarms of dykes and sills are present within the Assynt Culmination (Fig. 2); see Parsons (1999) and Goodenough et al. (2004) for reviews. The Loch Ailsh Pluton comprises feldspar- and pyroxene-syenite and has been dated at $439 \pm 4 \mathrm{Ma}$ (Halliday et al. 1987); it is generally regarded to predate thrusting along the Moine Thrust. The Loch Borralan Pluton comprises nepheline-, feldspar- and quartz-syenite and has been dated at $430 \pm 4 \mathrm{Ma}$ (van Breemen et al. 1979). In contrast to the Loch Ailsh Pluton, the Loch Borralan Pluton appears to truncate most thrusts within the Assynt Culmination.

\section{History of research}

The 'Highlands Controversy' was a long-lasting, and at times intense and acrimomious, mid- $19^{\text {th }}$ Century scientific debate concerned with the problem how non-fossiliferous metamorphosed rocks (Moine psammites) could overlie fossiliferous sedimentary strata (Durness 'limestone') on apparently concordant boundaries. Major scientific figures of the time such as Sir Roderick Impey Murchison, Professors Charles Lapworth and James Nicol, geologists Charles Callaway, Ben Peach and John Horne and Sir Archibald Geikie all examined, and argued over, the interpretations of key localities including Loch Erribol, Assynt, Ullapool and Kinlochewe. The scientific debate and the colourful lives of the participants has been comprehensively described by Oldroyd (1990); here only a summary focussing on Assynt is given.

The apparently simple geometry of the (single) Moine Thrust at Knockan Crag (Fig. 2), just south of the Assynt Culmination, convinced Murchison and his supporters of the existence of a simple stratigraphical sequence whereby unfossiliferous Moine rocks were deposited on fossiliferous limestone in simple succession; the Moine rocks were interpreted as Silurian in age. In contrast, James Nicol showed that such simplicity could not explain the local complexities of the geology in central Assynt. Nicol (1857) suggested the existence of a repetition of the quartzite-limestone sequence and attributed this to the existence of a steep (normal) fault near Inchnadamph in Assynt, roughly at the level of what later became known as the Sole Thrust (Fig 2.). Murchison however, spent some time in the valley of the River Traligill (Fig. 2), (apparently in the company of the "handsomest Highland lass I have ever seen"; Oldroyd, 1990, p 78) and convinced himself that all the rocks were in stratigraphical order. He reasoned further that a second quartzite occurred stratigraphically above the limestone and that the entire sequence was folded into broad, open folds (probably the Droighin antiform, or the Breabag Dome, now recognised as anticlinal thrust stacks, see below).. On a cross-section through Assynt however, Murchison (1867) did not show any kind of faulting, even though he must have seen the wellexposed and conspicuous Traligill Thrust. Much later, Callaway (1883) started to doubt the 'Murchisonian Doctrine' and his cross-sections of Cnoc an Droighin and Conival in Assynt (Fig. 4) are very reminiscent of modern-day cross-sections except that repetition of stratigraphical sequences was still mainly attributed to steeply-dipping faults rather than shallow-dipping faults (compare Oldroyd 1990, p210, with Coward 1982 and British Geological Survey 2007).

The 'Highlands Controversy' was intellectually solved by Charles Lapworth (1883, 1884) on the key outcrops near Loch Erribol, in the northern part of the Moine Thrust Belt. In the meantime, Archibald Geikie, who had previously supported the 'Murchisonian Doctrine' but had now superseded Murchison as Director of the Geological Survey, sent a team of surveyors led by Benjamin Peach and John Horne to the NW Highlands, to settle the issue once and for all. In the field, Peach and Horne were quickly convinced by Charles Lapworth of the validity and elegance 
of his solution involving low-angle thrust repetitions and so started to map the Loch Eriboll area in detail. Peach, Horne and colleagues gradually worked their way south along the entire thrust belt, producing exquisite geological maps along the way. Their work culminated with the classic Geological Survey memoir describing 'The geological structure of the NW Highlands of Scotland' (Peach et al. 1907) and publication of the 'Assynt Special Sheet' (Geological Survey of Great Britain, 1923).

Those publications did not however solve all of the geometrical problems, especially how one thrust might join with, or link into, another. For instance, one remaining problem was the northern termination of the Ben More Thrust, as discussed in Elliot \& Johnson (1980) and Krabbendam \& Leslie (2004); another problem was the southern continuation of the Glencoul Thrust near Inchnadamph, with different solutions proposed by Bailey (1935), Christie (1963) and Elliot \& Johnson (1980). Coward (1982) suggested the existence of large-scale 'surge-zones' involving linkage between frontal thrusts and extensional faults at the rear as a solution, a model rejected by Krabbendam and Leslie (2004).

\section{Overview of the Assynt Culmination}

The overall structure of the Assynt District is that of a bulge or culmination in the Moine Thrust plane (Fig. 2). The overall thrust movement was to the WNW (McClay \& Coward 1981), and most thrusts dip gently to the ESE. Within the Assynt Culmination, major individual thrust sheets broadly overlap each other in such a way that the more northerly thrust sheets overlie those to the south. The structurally highest, and also largest, thrust sheet is the Ben More Thrust Sheet (Fig. 2), with a strike length over $20 \mathrm{~km}$ (Krabbendam \& Leslie 2004); small klippen of the Ben More Thrust Sheet occur farther west (Peach et al. 1907; Coward 1985). The floor thrust in the culmination is defined as the Sole Thrust (Fig. 2), although this is not necessarily one single thrust plane. South of the Assynt Culmination, as at the classic Knockan Crag locality (now featuring a visitor centre dedicated to the geology of the Moine Thrust Belt), the Moine Thrust rests directly on the Foreland, so that the Moine Thrust and the Sole Thrust are effectively the same structure.

The Assynt Culmination is transected by the Traligill Transverse Zone (TTZ). This transverse zone trends WNW-ESE, sub-parallel to the thrust transport direction, and is associated with an en echelon fault system cutting thrusts, discontinuity of the thrust architecture, and oblique fold and thrust structures (Fig. 2). The effect of the Transverse zone on the Ben More and Moine thrusts is only minor but below the Ben More Thrust the thrust architecture differs greatly to north and south of the transverse zone; these differences are the focus of this paper.

\section{Thrust architecture north of Traligill Transverse Zone}

The area north of Traligill Transverse Zone is dominated by the Glencoul Thrust Sheet (Figs. 2, 4); this structure terminates near Loch Glencoul in the NW of the culmination (Krabbendam \& Leslie 2004). The northern part of the Glencoul Thrust Sheet comprises a single thick slab of Lewisian Gneiss, overlain by Basal Quartzite on Glas Bheinn and Beinn Uidhe (Fig. 4); the Glencoul Thrust emplaces Lewisian Gneiss over Durness Group dolostone in the footwall (Butler in Alison et al. 1988). Southwest of Ghlas Bheinn, the footwall of the Glencoul Thrust comprises the 'Achmore imbricates', dominated by Durness Group dolostone ; these were described in detail by Coward (1984) and are not considered further here. West of Glas Bheinn, Basal Quartzite occurs in the immediate hanging wall of the Glencoul Thrust; farther south (Point A on Figure 4), Pipe Rock is emplaced over the dolostone of the Achmore imbricates. The Glencoul 
Thrust, therefore, does lose some of its stratigraphical separation as the thrust ramps up through the hanging wall succession towards the south (Elliott \& Johnson, 1980).

South of Glas Bheinn and Beinn Uidhe, there are two large bodies of Lewisian Gneiss, in contrast to the single slab exposed north of those summits (Figs. 4, 6d). In three dimensions, these two bodies are flattened cylinders plunging to the ESE (Figure 6a). There are at least at least six subsidiary thrusts between the Glencoul Thrust and the overlying Ben More Thrust in this area: each of these, and the Glencoul thrust, are now described in turn from west to east. Most thrusts appear to be splays of the thrust that underlies the north side Beinn Uidhe and Glas Bheinn (Fig. 4).

\section{The Cnoc an Droighinn surge zone revisited}

East of Achmore Farm, the Glencoul Thrust emplaces Pipe Rock over Eilean Dubh dolostone of the Achmore Imbricates (Fig. 4). Some $100 \mathrm{~m}$ above the Glencoul Thrust, a subsidiary thrust, the Cnoc Dubh Thrust, emplaces Basal Quartzite over Pipe Rock and north of Point B, a c. $4 \mathrm{~km}^{2}$ outcrop of Lewisian Gneiss rests on the Glas Bheinn Thrust. The gneiss is unconformably overlain by Basal Quartzite near Point B (Fig. 4) but the eastern contact of the Lewisian Gneiss is also a thrust (the Cnoc an Droighinn Thrust) that locally emplaces Pipe Rock onto Lewisian Gneiss (Point C). Near Point D, east-dipping dip slopes of Pipe Rock occur, whilst farther east Basal Quartzite occurs at Point E. This suggests the presence of another thrust, termed here the Poll an Droighinn Thrust between these two points, although outcrop is poor. The Poll an Droighinn Thrust is interpreted here as a later breaching thrust (see below). Farther east, and structurally higher still, is the Beinn Uidhe Thrust, which has the eastern body of Lewisian Gneiss in its immediate hanging wall. In the north, the Beinn Uidhe Thrust is traced along the SW slopes of the Beinn Uidhe plateau (via point $\mathbf{H}$ ), emplacing Basal Quartzite over Pipe Rock, whilst to the south the thrust is traced along the slopes beneath the Beinn an Fhurain plateau (point G). A further subsidiary thrust (the Loch nan Cuaran Thrust) occurs east of, and structurally above, the higher Lewisian Gneiss body; this thrust is a splay branching off the Beinn Uidhe Thrust at points $\mathbf{G}$ and $\mathbf{H}$. The thrust has only minor displacement but commonly thickens Pipe Rock or Basal Quartzite, and locally emplaces Basal Quartzite over Pipe rock (east of Point G, Fig. 4). North of Poll an Droighinn between the Glencoul and Ben More Thrusts, it not only appears there is repetition (in map and section view, Figs. 4 and 6a) of the two Lewisian Gneiss bodies but also of the thrusts surrounding the two bodies. Thus, the Beinn Uidhe Thrust appears to be equivalent to the Glas Bheinn Thrust, both carrying Lewisian Gneiss in their hanging walls. The Cnoc an Droighinn Thrust is equivalent to the Loch nan Cuaran Thrust, both minor thrusts structurally above the Lewisian Gneiss bodies. Coward (1982) suggested that the two areas of gneiss were originally part of a single mass, disrupted by a NW-dipping extensional fault as part of a 'surge zone'. This putative extensional fault would extend from Inchnadamph NE ward, via Poll an Droighinn and point I, to the Leathaid Riabhaich gully and would have resulted in the western Lewisian Gneiss body being dropped down by some $400 \mathrm{~m}$ to the west with respect to the eastern body (Coward 1982). The new revision mapping however demonstrates that strata and thrusts between Beinn Uidhe and Beinn an Fhurain show too much continuity to allow such displacement and invalidates the interpretation of Coward. Furthermore, we find no evidence that the cross fault identified in the lower reaches of the Allt Poll an Droighinn continues to the NE towards Point $\mathbf{I}$, rather it trends E-W and probably connects to cross-faults farther east near Point G (Poll an Droighinn Fault on Fig. 4). Moreover, the northern cross fault near Point I displaces the Beinn Uidhe thrust and a small fold and has limited $(<50 \mathrm{~m})$ down-to-the-east displacement. . 
The contact at Leathaid Riabhaich was re-interpreted by Krabbendam \& Leslie (2004) as the trace of the Ben More Thrust, steepened above an oblique culmination wall, rather than an extensional fault.

We prefer instead to explain the gross duplication by a breaching thrust that repeated an already thickened series of thrust sheets. The most likely candidate for such a breaching thrust is the Poll an Droighinn Thrust (Figs. 4, 6a); some (later?) breaching movement may also have been taken up by Cnoc an Droighinn Thrust, as this locally emplaces Pipe Rock over Lewisian Gneiss (Point C), a younger-over-older relationship commonly seen with breaching thrusts.

\section{The Droighinn Anticlinal Stack}

The thrusts traced southward from Cnoc an Droighinn are folded over an anticlinorium - the Droighinn Anticline of Bailey (1935) and Coward (1982), (Fig.4). This fold is presumably formed by antiformal stacking of underlying thrust imbricates; however, the core of the anticlinal stack is nowhere exposed and so its components and internal architecture cannot be constrained (Fig. 6d). North of the Poll an Droighinn Fault at least two antiformal folds occur, separated by the Glas Bheinn Thrust; to the south of the Fault the antiform continues as a single structure and crosses the River Traligill at the trace of the Gleann Dubh Fault (Point J, Fig. 4). The continuity of the anticline across the Poll an Droighinn Fault implies that this cross-fault cannot have significant displacement (Bailey 1935; c.f. Coward 1982). The axis of the Droighinn Anticline trends c. $130-310^{\circ}$, markedly oblique to the thrust transport direction (Coward \& Kim, 1981).

South of the Poll an Droighinn Fault, the Droighinn Anticline has a monoformal profile with a gently NE-dipping limb and a moderate to steeply SW-dipping limb, the latter exposing extensive quartzite dip-slopes. On the NE limb three thrusts occur: the uppermost is the Beinn Uidhe Thrust, marked by a small occurrence of Lewisian Gneiss in the immediate hanginwall in the north (near Point G). The middle thrust is termed the Beinn an Fhurain Thrust marked by a distinct nick in the west slope of Beinn an Fhurain; here it emplaces a folded sequence of Basal Quartzite and Pipe Rock over Pipe Rock and a thin sliver of An t-Sron Formation (Point F). The Beinn an Fhurain Thrust possibly links with the Poll an Droighinn Thrust. The lowermost thrust is discussed later.

\section{Thrust architecture south of Traligill Transverse Zone}

The thrust architecture south of the Traligill Transverse Zone is dominated by the Breabag Stronchrubie system that stretches from the Sole Thrust in the east, to Glen Oykel in the west where it is overlain by the Ben More Thrust (Figs. 5, 6b, 6c). In the north, the Traligill Thrust ( $\mathbf{T r}$ on Fig. 5) forms a convenient boundary, whilst in the south the system appears to be truncated by the Loch Borralan Pluton in an area of poor exposure. The quartzite-dominated Breabag Dome structure in the east and the dolostone-dominated Stronchrubie imbricates in the west were regarded by Peach et al. (1907), and by Elliott \& Johnston (1980), as separate thrust systems. However, Coward (1984) demonstrated that individual horses can be traced from the Breabag Dome into the Stronchrubie imbricates, thus collectively forming a single thrust duplex system. Coward's work (1984) is, with only minor modifications, the basis of the published revised geological map and cross-section for this area (British Geological Survey 2007). The thrust sheets are arranged within an anticlinal stack termed the Breabag Dome (Fig. 6c), such that strata dip westward towards the Foreland on the western slopes of Breabag and are commonly wellexposed in large-scale dip-slopes. East of the hinge, thrusts and strata dip eastward. The axis of the Breabag Dome trends north-south and approximately follows the summit ridge of Breabag 
(Fig. 5). The thrusts in the Stronchrubie imbricate system dip gently to the east and the hinge zone of the gentle intervening, north-south syncline underlies the three klippen of Cnoc nan Uamh, Beinn nan Cnaimhseag and Beinn an Fhuarain. The latter two klippen comprise Torridon Group rocks and quartzite and are generally regarded as part of the Ben More Thrust sheet (Peach et al. 1907; Geological Survey of Great Britain1923; Elliot \& Johnson 1980). In contrast, the Cnoc nam Uamh Klippe contains Pipe Rock and An t-Sron Fm and is described further below.

The Breabag Dome comprises at least six discrete thrust sheets, with the lowest thrust (1) exposed in the topographical depression of Cùil Dhubh (point $\mathbf{P}$ on Fig. 5), and the highest (6) in the SE near Point $\mathbf{Q}$ (Fig. 5). Thrusts (2), (3) and (4) have a considerable strike length (c. $8 \mathrm{~km}$ ) and can be traced from the Loch Borralan Pluton in the south to Gleann Dubh and Bealach Traligill. However, subsidiary thrust (5a) is confined to Breabag and Glen Oykel, and the positions of the westerly branch points of this thrust are reasonably well constrained on the ridge of Breabag (see purple dots marking branch points on Figure 5). The easterly branching points are less well constrained as they occur in the poorly exposed valley floor of Glen Oykel. Thrust (4a) only occurs in the southern part of the Breabag Dome.

Individual thrust sheets climb stratigraphy towards the west, so that their trailing edges contain quartzite and their leading edges contain dolostone (Coward, 1984). This is best illustrated in thrust sheet (2) which exposes westerly dip-slopes of Pipe Rock and minor Basal Quartzite on the western slopes of Breabag, with wide outcrops of Fucoid Beds in the low ground near point $\mathbf{R}$ (Fig. 5), giving way to gentle east-dipping to sub-horizontal Durness dolostones farther west in the same thrust sheet.

In Glen Oykel in the east, three small inliers of Lewisian Gneiss, overlain by Basal Quartzite, occur within thrust sheets (4) and (5). This shows that these high-level thrust sheets 'sampled' the basement gneiss but it is not known whether the large thrust sheets farther west and lower down in the structural pile (e.g. thrust sheets (2) and (3)) also 'sampled' Lewisian Gneiss, as the critical levels are nowhere exposed. The eastern flank of the Breabag Dome is a composite fold-and-thrust duplex system and incorporates a number of separate fold hinges, some of which are spectacularly exposed, e.g. near point $\mathbf{S}$ (Fig. 5). The very sinuous exposure pattern of thrust (5a) around point $\mathbf{T}$ is a consequence of the intersection of the valley topography and the monoformally folded profile of the thrust.

South-east from Inchnadamph, a large boggy area is underlain mainly by Eilean Dubh Formation dolostones. A great number of subsidiary thrusts occur in the so-called Stronchrubie imbricates. Two of these carry a sliver of the Sailmhor Formation, the highest stratigraphical level preserved in the Assynt District. Near point $\mathbf{U}$ on Fig. 5, the lower imbricates are admirably exposed in the Stronchrubie cliffs (a classic excursion stop, see Butler, in Alison et al. 1988) and it can be seen that the Stronchrubie thrust functions as the floor thrust to this system. The Stronchrubie Thrust lies c. $70 \mathrm{~m}$ structurally above the Sole Thrust, which occur at the base of the Stronchrubie cliffs. Towards the NE, imbricates of Eilean Dubh Formation (locally also with Ghrudaidh Formation) root into the Traligill Thrust (point $\mathbf{V}$ on Fig. 5). The Traligill Thrust dips c. $20^{\circ}$ to the SSW, and probably links with the Stronchrubie Thrust, albeit reoriented later (see below). That stated, a direct link between these two thrusts has not been established due to structural complexity and paucity of outcrop in the area immediately SE of Inchnadamph

\section{The Cnoc nan Uamh Klippe}


The Cnoc nan Uamh Klippe (Fig. 5) contains Pipe Rock, Fucoid Beds, and Salterella Grit; the klippe structurally overlies dolostones of the Stronchrubie imbricates. Subsidiary thrusts occur within the klippe and emplace Pipe Rock over Fucoid Beds and create repetitions of Fucoid Beds and Salterella Grit. Some $500 \mathrm{~m}$ to the east is another small klippe of steeply dipping Pipe Rock; this klippe and the Cnoc nan Uamh klippe probably belong to the same thrust sheet. It is unlikely that the Cnoc nan Uamh klippe belongs to the Ben More Thrust Sheet, since klippen to the south comprise mainly Torridon Group rocks. A link with the Beinn an Fhurain or Beinn Uidhe thrust sheets is more likely, but cannot be proven.

\section{Summary of thrust structures on either side of the transverse zone}

To summarise, north of the Traligill Transverse Zone there are two major thrusts, repeated by later breaching. The thrust sheets are relatively thick (up to $500 \mathrm{~m}$ ) and individual thrusts must have taken up several kilometres of displacement in order to emplace Lewisian Gneiss over Pipe Rock (Fig. 6a). Thrusting involved thick slabs of Lewisian Gneiss and Eriboll Formation quartzite; stratigraphically higher formations are essentially absent, so that thrusting clearly worked low in the stratigraphical succession and 'dug' deep into basement.

In contrast, thrusting to the south of the TTZ is predominantly thin-skinned, involving mainly cover strata. Thrust sheets are much thinner and more numerous (at least 6) than north of the TTZ. Thrust sheets typically lack the incorporation of thick slices of basement gneiss.

\section{Traligill Transverse Zone and its cross faults}

Any attempt to establish links (or otherwise) between the different thrust geometries on either side of the Traligill Transverse Zone, necessitates the study of the high-angle en-echelon fault system that is associated with the transverse zone. That system of faults is aligned with the Proterozoic WNW-ESE trending Stoer Shear Zone, which has been identified within the Lewisian Gneiss in the Foreland (Cartwright et al. 1987, British Geological Survey 2002a, 2007). The Stoer Shear Zone, although not studied in detail, is similar to the Canisp Shear Zone farther south (Fig. 2). The Canisp Shear Zone is a km-wide shear zone, formed by repeated ductile movement during the so-called Inverian amphibolite-facies event at c. $2500 \mathrm{Ma}$ and more localized 'Laxfordian' movement between 1700 and 1600 Ma (Attfield 1987, Park et al. 2002). Beacom et al. (2001) showed that the Canisp Shear Zone also experienced wide-spread brittle reactivation. The Stoer Shear Zone can be traced to the western end of Loch Assynt. Loch Assynt is a (glacial) erosional trough excavated along a fault that displaces the CambroOrdovician sequence and the Sole Thrust (see below); this fault is termed here the Loch Assynt Fault. It is likely that the Loch Assynt Fault represents brittle reactivation of (part of) the Stoer Shear Zone.

Farther ESE within the Assynt Culmination, there are two separate faults (Gleann Dubh Fault, Bealach Traligill Fault), arranged in en echelon fashion (Figs 4, 5, $7 \mathrm{a}, \mathrm{b}$ ). The Gleann Dubh and Bealach Traligill Fault have an overlap of c. $1 \mathrm{~km}$ and a c. $300 \mathrm{~m}$ wide relay ramp. Between the Gleann Dubh and the Loch Assynt Fault there is no overlap; instead there is a c. 2 $\mathrm{km}$ long gap without fault separation (between the Cnoc nam Uamh Klippe and Inchnadamph; Fig. 5). There are three separate piercing point pairs that constrain the true displacement of the different segments of this cross-fault system. Each is assessed in turn below. 
In the east, the Bealach Traligill Fault (also called Traligill Pass Cross Fault, Elliott \& Johnson 1980) has a strong topographical expression near point $\mathbf{W}$; here a spectacular gorge is lined with strongly fractured and locally brecciated quartzite (Figs. 5, 7a,b). In the east, this fault displaces the Moine Thrust and the Ben More Thrust Sheet, with an apparent sinistral displacement of c. $250 \mathrm{~m}$ (see also Fig. 2). West of the Ben More Thrust, precise constraints are provided by the displacement of An t-Sron Formation on either side of the fault, WNW of Bealach Traligill (Fig 5, 7b). The axis of the Breabag Dome fold provides a reliable piercing point that further constrains fault displacement. The displacement is c. $360 \mathrm{~m}$, with a sinistral strike slip component of c. $300 \mathrm{~m}$ and a downthrow to the NE of c. $200 \mathrm{~m}$ (Fig. 7c).

The Bealach Traligill Fault stops short of the trace of the Droighinn Anticline and displacement is taken up on another fault, the Gleann Dubh Fault, in an en echelon arrangement (Fig. 7b). This fault displaces the Droighinn Anticline, the axis of which provides another reliable piercing point. The displacement of this piercing point involves c. $90 \mathrm{~m}$ sinistral with c. $20 \mathrm{~m}$ downthrow to the NE (Fig. 7d). This strike-slip movement is corroborated by shallow NEplunging slickenlines on an exposed fault surface at [NC 2795 2065]. This segment of the fault must die out towards the NW, as the SW limb of the Droighinn Anticline shows little or no displacement.

In the Foreland, the Loch Assynt Fault displaces the so-called Double Unconformity. The Double Unconformity is the intersection of the base-Cambrian unconformity, which dips c. 10-12 degrees to the east, and the base-Torridon unconformity, which is broadly sub-horizontal. This intersection line trends NNE-SSW (Fig. 7a), at high angles to the Loch Assynt Fault. On the south side of Loch Assynt, the Double Unconformity intersection is about $100 \mathrm{~m}$ above loch level, whilst on the north side it lies c. $20 \mathrm{~m}$ below loch level. Piercing point analysis shows that the Loch Assynt Fault has a sinistral displacement of c. 1300 m, with a downthrow to the NE of c. $120 \mathrm{~m}$ (Fig. 7e).

The Loch Assynt Fault, lying outside the thrust belt, records the cumulative fault displacement accumulated since deposition of the Cambro-Ordovician sequence, i.e. the sum of pre-thrust, syn-thrust and post-thrust displacements. In contrast, the Glean Dubh and Bealach Traligill Faults only record displacement accumulated since the formation of the anticlinal fold structures, i.e. syn- and post-thrust displacements. The cross-faults within the Traligill Transverse Zone thus experienced c. $1000 \mathrm{~m}$ of sinistral displacement along the Loch Assynt segment prior to thrusting, but were reactivated after thrusting, with only some $300 \mathrm{~m}$ syn- to post thrusting displacement. The model in Fig. 8 summarises the main features of the pre-thrust template, illustrating how prior to thrusting a c. $100 \mathrm{~m}$ high step in the cover and basement had developed. Two conclusions can be drawn from this piercing point analysis:

1) Sedimentary strata did not form continuous, uninterrupted planes prior to thrusting, but had already been transected, and displaced, by one (or more) normal faults, whose trend was at a small angle to the subsequent thrusting direction;

2) Displacements within the thrust belt (along the Gleann Dubh and Bealach Traligill faults) are limited, thus potentially allowing for reliable linkages to be established between the thrust system north and south of Traligill.

\section{Links across the Traligill Transverse Zone}


The Ben More Thrust and the Sole Thrust can be easily traced across the Traligill Transverse Zone (Figs. 2, 5). Around Bealach Traligill, the sequence of An t- Sron and Ghrudaidh formations that crops out on either side of the Bealach Traligill Fault provides an important marker (point $\mathbf{W}$ on Figs. 5, 7). These rocks are overlain by a major thrust (6), carrying Basal Quartzite. This thrust can be traced through the west wall of Conival towards the north to thrust (6'), where it links directly with the Beinn Uidhe Thrust. The Beinn Uidhe Thrust and Thrust (6) merge with the Ben More Thrust some $600 \mathrm{~m} \mathrm{SE}$ of Bealach Traligill (Fig. 5).

Similarly, thrust (5), which carries An t-Sron and Ghrudaidh formations in its hangingwall, can be confidently traced across to the north side of the Bealach Traligill Fault (as thrust 5'). However, its fate farther to the NNW is unclear. The region around point $\mathbf{X}$ (Fig. 5) is extremely complicated and only moderately well exposed. Overall, the situation is that the axis of the Breabag Dome plunges to the north, whilst the Droighin Anticline plunges towards the SE, both towards Point $\mathbf{X}$. A tight, cuspate synclinal saddle structure lies in between. Moreover, numerous thrusts appear to branch off from each other, both near point X and farther NW (see purple dots on Figure 5), in an interlocking manner, so that it becomes a difficult to establish which individual thrust links with which.

Lower down in the thrust pile, the Traligill Thrust is a major thrust, well exposed in the Traligill Valley ( $\boldsymbol{T r}$ on Figs. 4, 5). Here, it strikes WNW -ESE, sub-parallel to the thrust transport direction. Imbricates of Durness Group dolostones which belong to the StronchrubieBreabag system are well-defined in the hanging wall of this thrust, and it is likely that the Traligill Thrust and the Stronchrubie Thrust are the same structure (see earlier discussion). A continuous sequence all the way down from Eilean Dubh Formation to Basal Quartzite occurs in the footwall of the Traligill Thrust, (this is probably the sequence which led Murchison astray). The strata in the footwall of the Traligill Thrust and the thrust itself are folded by the Droighin Anticline. Consequently, the Traligill Thrust can be traced beneath the Cnoc an Uamh Klippe, is folded over by the Droighinn Anticline, and links to the westernmost thrust below Beinn an Fhurain (termed here the Northern Traligill Thrust, Fig. 4; see also Elliott \& Johnson 1980, Fig 15). The key now is how this Northern Traligill Thrust links with those to the north of Poll an Droighinn Fault (Figs. 4, 6d). If the Beinn an Fhurain Thrust links with the (breaching) Poll an Droighinn Thrust, than it is likely that the Northern Traligill Thrust links with Glas Bheinn Thrust and that the Glencoul Thrust underlies or splays southwards into the concealed Droighinn Anticlinal Stack (e.g. Elliot \& Johnson 1980). Another (end member) possibility is that the Poll and Droighinn breaching thrust and its related breaching peters out near Poll an Droighinn; in that case the Beinn an Fhurain Thrust links with the Cnoc Dubh Thrust (folded over the Droighinn Anticline) and the Northern Traligill Thrust could link with the Glencoul Thrust, again folded over the Droighinn Anticline. This is attractive as both the Glencoul and Traligill thrust serve as major floor thrusts, but it would require that the Droighin Anticline developed after the development of the Glencoul - Traligill - Stronchrubie Thrust system.

In summary, some individual thrusts can be linked across the Traligill Transverse Zone, e.g. thrust (6) with the Beinn Uidhe Thrust. The Traligill Transverse Zone in upper Gleann Dubh is marked by a cuspate synclinal saddle, in between the two lobate anticlines (Droighinn and Breabag Dome). Whether the Glencoul Thrust links directly to the Traligill Thrust is uncertain, but overall the Glencoul Thrust Sheet (sensu lato) grades into the Breabag - Traligill Stronchrubie imbricate system by extensive splaying or interfingering with some thrust sheets wedging out to the north, and others to the south (Fig. 6d). 


\section{Discussion}

The Traligill Transverse Zone that disrupts the thrust structure in Central Assynt has the following pertinent characteristics.

- The Traligill Tranverse Zone developed sub-parallel to, and structurally above, a preexisting fault (the Loch Assynt Fault) that displaced both basement and cover prior to thrusting. Fault displacement was sinistral with a component of down-throw to the NE. No stratigraphical changes occur across fault; the fault is post-depositional (post EarlyOrdovician), although it reactivated the long-lived ductile Proterozoic Stoer Shear Zone identified in the Lewisian basement. Minor displacements occurred syn- to post-thrusting.

- The thrust system to the south is characterised by numerous, thin thrust sheets, mainly involving thin cover strata; to the north there are fewer but thicker thrust sheets, involving thick basement slivers. The thrust front in the north also propagated further, resulting in a bend in the thrust front. The two thrust systems are linked by complex interfingering and branching across the Traligill Tranverse Zone.

- The Droighinn Anticline in the north and the Breabag Dome axis in the south both plunge towards the cross-fault; the complimentary synform in the centre is an extremely complicated, cuspate saddle structure.

- The vertical displacement on the Loch Assynt Fault (c. $100 \mathrm{~m}$ ) is relatively small compared to the scale of the transverse zone. On the NE side of the fault system, the amplitude of the Droighinn anticlinal stack is of the order of $1000 \mathrm{~m}$ (Figure 6d). It thus appears that the scale and complexity of the disturbance associated with the Traligill Transverse Zone grew larger with time, starting from an original relatively minor disturbance. This may be explained, at least in part, by oblique 'piling-up' of thrust sheets by sinistral transpression against the initial basement step.

- Sinistral transpression is likely to have occurred as a consequence of the small angle between the strike of the Loch Assynt Fault $\left(305^{\circ} \mathrm{N}\right)$ and the thrust transport direction (c. $290^{\circ} \mathrm{N}$; McClay and Coward 1981); this is schematically shown on Fig. 8. Sinistral transpression is also supported by the strain measurements (using Skolithos pipes as strain markers) of Coward and Kim (1981). They documented moderately strong sinistral shearing combined with east-west to ENE-WSW contraction within thrust sheets on the north side of the Traligill Transverse Zone. The highest sinistral shearing $(\gamma=0.5-0.6)$ was observed in the core of the Droighinn Anticline. It should be noted that the oblique orientation of the Droighinn Anticline (within c. $20^{\circ}$ of the thrust transport direction) cannot solely be explained by rotation of the fold axes (like sheath folds or flow perturbation folds, Cobbold and Quinquis 1980; Alsop and Holdsworth 2004); the sinistral shear strains measured by Coward and Kim (1981) are not sufficient $(\gamma<0.6)$ to generate such a rotation. Instead the Droighinn Anticline, and its associated (concealed) anticlinal stack, must have primarily formed in a highly oblique orientation, with little subsequent rotation (see also Coward \& Kim, 1981 and Coward and Potts 1983); again this is consistent with local transpression.

Transverse zones and their origin: comparisons with other thrust belts Thrusts and nappes in many fold-and-thrust belts commonly show a remarkable lateral continuity (eg. Canadian Rocky Mountains; Price, 1981), all thrusts and nappes have to stop somewhere. Abrupt lateral changes in thrust architecture commonly occur along so-called transverse zones. 
Structures that connect thrusts from one side to the other across the transverse zone can include lateral and oblique ramps and strike-slip faults, grouped together as "lateral connectors" (Thomas, 1990). Specific studies on lateral thrust terminations and transverse zones in thrust belts include studies in the Appalachians (Mitra 1988, Thomas and Bayona 2002); Rocky Mountains in Utah (e.g. Paulsen \& Marshak 1988, 1997) and in Canada (Fermor 1999; Bégin and Spratt 2002); the Andes (Mon et al. 2005, Hinsch et al. 2002); Alps (Laubscher 1985); Pakistan (McDougall and Khan 1990) and the Pyrenees (Soto et al. 2002). Less sharp changes in thrust architecture involving curvature of the thrust front are related to the salient-recess problems and are particularly well studied in the Appalachians (e.g. Tull \& Holm 2005).

Transverse zones in thrust belts can have a number of causes. On the large-scale, one of the tectonic plates involved can be an indentor, the India - Asia collision being a good example. At the edges of such an indentor numerous strike-slip and transverse zones are likely to develop (McDougall \& Khan 1990). However, there are a number of smaller-scale causes, more relevant to this study in the Moine Thrust Belt:

1) Lateral facies changes in the stratigraphy without basement faulting (Fig. 9a). Such changes, however, are not necessarily aligned with the thrust transport direction, nor concentrated along a particular zone. Such changes, therefore, would be expected to have a gradual, tapering effect on the overall thrust geometry, a good example being the study of Soto et al. (2002) in the southern Pyrenees. However, if the lateral facies changes involve 'easy glide horizons' (e.g. shale or evaporates) the effects may be more pronounced.

2) A basement fault not affecting overlying strata, with the cover strata having a flat unconformity (Fig. 9b), i.e. without post-depositional displacement. Such a structure would only affect the thrust architecture if thrusting involved the basement. An additional effect may develop if there is a distinct difference in orientation of the principal fabric within the basement, for instance if the fabric is sub-horizontal on one side and subvertical on another. Lateral changes within the Moine Thrust Belt across the Laxford Shear Zone may be a good example of this situation (see also discussion below).

3) Thickness variations in the stratigraphy above a basement fault (Fig. 9c); in this case the basement fault must have been active during deposition of the cover strata. In the Sevier fold-thrust belt, Utah, Paulsen \& Marschak (1999) document a thickness variation in Proterozoic to Permian strata from 3 to $9 \mathrm{~km}$ across the Charlestown Transverse Zone; this thickness variation is interpreted to be the result of normal faulting in the Precambrian basement. On the down-thrown side, where the sedimentary package is thickest, thrusts propagated farthest onto the foreland and involved thick thrust sheets, comprising sedimentary strata only. On the up-thrown side, basement slices are involved in the thrusting. The Charlestown Transverse Zone above the interpreted basement fault links thrusts on either side via a complex zone of lateral ramps and strike-slip faults. At a late stage (possibly due to a slight change in transport direction to a more transpressive regime?) the Uinta-Cottonwood arch developed, oriented at right angles to the thrust front.

4) A basement fault that affected overlying strata after deposition, so that the cover strata rest upon a planar unconformity, which is subsequently displaced (Fig. 9d); this is the situation described in the Traligill Transverse Zone. Such a fault would have an effect on 
the thrust architecture if thrusting affected cover rocks only, but also if it affected cover and basement.

Calassou et al. (1993) used sand box modelling to study the effects of a basement fault in the footwall exactly parallel to the thrust direction, but with a uniform hangingwall, very much like the situation (4) above. The model of Calassou et al. (1993) showed:

1) lateral interfingering of thrust sheets, both in map view and in cross-section along the tranverse zone,

2) thrusts developing above the down-thrown side of the basement fault propagating further on the foreland, defining a bend in the thrust front,

3) a different thrust geometry in the compartments on either side of the transverse zone, with fewer but thicker thrust sheets on the downthrown side.

These features are similar to the situation across the Traligill Transverse Zone. However, the difference with Assynt is that the scale of the transverse zone in the models is proportional to the basement step, and no oblique anticlinal stacking developed. This is probably because the basement fault in the models was positioned exactly parallel to the thrust transport direction, a situation that would be rare in nature.

An additional factor of importance, therefore, is the angular relationship between the strike of the pre-existing fault and the subsequent thrust transport direction. In Figs. 9c and 9d, if the transport direction is clockwise from the strike of the fault, thrusts need to ramp up and over the basement step, and local transpression is expected. Conversely, if the transport direction is anticlockwise from the strike of the fault, thrusts would 'descend' the basement step, and local transtension is expected.

In many cases where pre-existing basement faults are invoked as a parent structure to a transverse zone, the contact of the transverse zone with the basement is concealed by external parts of the thrust belt or by its foreland basin. For instance, in the Canadian Rocky Mountains, a number of lateral changes in thrust architecture are well documented and thought to relate Proterozoic basement shear zones (eg. McMechan 2002; Bégin and Spratt 2002 and references therein). However, a $400 \mathrm{~km}$ wide foreland basin separates the thrust front from Proterozoic outcrop and the nature of the shear zones can only be constrained by drilling and geophysical means (eg. Ross et al. 1991; Pana 2003). This means for instance that in NE British Columbia (McMechan 2002) it is difficult to distinguish between scenario 3) and 4) above. In the case of the Moine Thrust Belt post-Caledonian tilting, uplift and erosion has fortuitously revealed the foreland basement in contact with the thrust belt, allowing good constraints on the character and displacement of the pre-existing basement structure, and its link with the thrust belt, as shown by the detailed piercing point analysis.

Other transverse zones in the Moine Thrust Belt and Moine Nappe

The Lewisian gneiss basement in the Foreland of the Moine Thrust Belt contains a number of WNW-ESE striking Palaeoproterozoic shear zones (Fig. 1; Coward \& Park 1987, Attfield 1987, Beacom et al. 2001, Kinny et al. 2005). In outline, the effects of these shear zones on the Moine Thrust Belt are as follows (described from north to south - see Fig. 1 for locations): 
1) The Rispond Shear Zone is a steep zone of ductile shearing (Ramsay 1997). The later Faraid Head Fault lies parallel to the shear zone and is long recognised to be responsible for down-faulting the Moine Thrust Belt to the north (Peach et al. 1907), probably during the Devonian or Permo-Triassic (Holdsworth et al. 2007). There is no direct evidence that the Rispond Shear Zone was reactivated as the Faraid Head Fault (Holdsworth pers. comm. 2008). Moreover, where the shear zone runs under the thrust belt, the thrust architecture is dominated by the Arnaboll, Lochan Rhiabhach and Moine thrusts. These thrusts are rather continuous along strike and do not show a pronounced transverse zone across the projected trace of the shear zone (Holdsworth et al. 2007; British Geological Survey 2002b). Farther SE (south and east of Eriboll) there are lateral ramps in the thrust belt (Holdsworth et al. 2006); the nature of the Rispond Shear Zone here is unclear and a link between the two structures would require further study.

2) The Laxford Shear Zone is a wide shear zone (Beach et al. 1974; Goodenough et al. 2009; this volume), the southern part of which lines up with Loch More. Here, neither the Sole Thrust nor the Cambro-Ordovician sequence in the Foreland are much displaced, so little post-Ordovician movement has occurred on faults related to the Laxford Shear Zone. As no Torridon Group rocks occur in the Foreland or in the thrust belt in this region, it cannot be determined whether post-Torridon movement occurred along the shear zone. However, c. $2 \mathrm{~km}$ south of Loch More is a major oblique ramp (Elliot \& Johnson 1980) marking the termination of a large thrust sheet with a thick basement sliver, with the Bhuirich Dome also occurring here (Butler 1984, British Geological Survey 2007). It is likely that these major lateral changes in thrust architecture were at least in part rooted above the Laxford Shear Zone.

3) The Stoer Shear Zone underlies the Traligill Transverse Zone as already described.

4) The Canisp Shear Zone is another wide shear zone, associated with a monoclinal steepening of the fabric in the Lewisian basement (e.g. Attfield 1987) and demonstrable brittle reactivation (Beacom et al. 2001). The Sole Thrust and base-Cambrian unconformity in the Foreland are not appreciably displaced. Nevertheless, the Canisp Shear Zone does line up with the Loch Borralan Pluton and the approximate southern termination of the Ben More Thrust Sheet (British Geological Survey 2007). It also approximately lines up with the Oykel Transverse Zone (Leslie et al. 2009, this volume), see below.

5) The Gruinard Shear Zone coincides with the apparent northern termination of the Kinlochewe Thrust Sheet. It should be noted that between the Assynt Culmination and the Kinlochewe Thrust Sheet, there are only a few small-scale culminations (at Langwell, Ullapool, Dundonell) and that the Moine Thrust over much of this segment is a simple, smooth structure.

6) The Loch Maree Fault is a major NW-SE trending fault, associated with a number of other faults and parallel to relatively narrow Proterozoic (Laxfordian) shear zones (Park 2002). It has major pre-Torridon movement (slicing the outcrop of the Loch Maree Group in two) as well as post-Torridon movement, which near Poolewe in the west must have dropped down the base-Stoer Group unconformity by at least $1500 \mathrm{~m}$ (Park 2002, British Geological Survey 1999). In the east, the Loch Maree Fault cuts through the entire Moine Thrust Belt and thus must have also experienced post-Caledonian movement. The Loch Maree Fault is coincident with the SE boundary of the Kinlochewe Thrust Sheet comprising a thick sheet of Lewisian Gneiss with minor Torridon Group 
rocks. It forms the NW boundary of the Achnashellach Culmination, which is characterised by medium-thick skinned thrusting involving abundant Torridon Group rocks and minor basement slivers (Butler et al. 2007). The thickness of Torridon sandstone in the Achnaschellach thrust sheets is considerably more than in the Kinlochewe Thrust Sheet (Butler et al. 2007).

7) The Torridon Shear Zone (also termed Diabaig or Shieldaig Shear Zone) at Loch Torridon (Wheeler et al. 1987; Wheeler 2007) lines up to the SE with a change from the Achnashellach Culmination in the north to (in the south) thin-skinned thrusting of Cambro-Ordovician strata at Loch Kishorn and the Kishorn Nappe, with its massive basement slice in Lochcarron and even larger Lochalsh fold-nappe (e.g. Coward \& Potts 1985). However, neither the Sole Thrust nor the base-Cambrian unconformity are displaced in this area, suggesting lack of Palaeozoic or later reactivation along this shear zone.

8) The Oykel Tranverse Zone is a major transverse zone in the ductile Moine Nappe, above the Moine Thrust, to the SE of the Assynt Culmination, (Leslie et al. this volume). In part due to the thick uniform nature of the Morar group rocks, thrust sheets are thicker and the whole process works on a larger scale. Regional gravity data modelling have been used to argue that the Oykel Transverse Zone was generated above an underlying ramp in the basement-cover interface (Leslie et al. this volume). This ramp is interpreted as the result of re-activation of a WNW-ESE trending sub-vertical basement shear zone, possibly the Canisp Shear Zone.

Overall, it is clear that the lateral variations in thrust architecture along the length of the Moine Thrust Belt are strongly influenced by the existence of Proterozoic shear zones, and the brittle faults that commonly developed along these shear zones. These shear or fault zones trend WNWESE to NW-SE, and were thus aligned at small angles $\left(10-15^{\circ}\right)$ to the thrust transport direction (towards c. $290^{\circ}$ ). Some faults cut through the entire thrust belt (Loch Maree Fault); other faults appear not to have displaced the base-Cambrian unconformity (Laxford Shear Zone, Torridon Shear Zone; see scenario depicted in Fig. 9b), but still appear to mark lateral changes in thrust geometry, others have little influence. These different relationships depend probably upon whether or not the causal structures experienced Neoproterozoic or Palaeozoic (brittle) reactivation, displacing the Torridon or Cambro-Ordoovician sequence. It is probable that many of the NW-SE shear zones were reactivated during Iapetan rifting as transfer or strike-slip faults, separating normal-fault blocks (c.f. Lister et al. 1986). Superficially, it appears coincidental that such (rather distal) rift-related transfer zones would be appropriately oriented to become thrustrelated transverse zones, several hundred million years later. However, if continental collision and related thrusting is approximately frontal with respect to the older rifted, passive margin it deforms, than such 'coincidences' may become the rule rather than the exception, as also argued in the Appalachians (Tull \& Holm 2005).

\section{Conclusions}

The Traligill Tranverse Zone in the Assynt Culmination in the Moine Thrust Belt marks a pronounced lateral change in thrust architecture. To the south, thrusting is predominantly thinskinned and involved mainly cover strata dominate whilst to the north few, but thick-skinned, thrusts sheets were generated, each typically containing thick basement slivers. This northern domain also was thrust farther onto the Foreland. Whilst some individual thrusts can be linked, 
there is extensive interfingering of thrusts across the transverse zone. A large oblique anticlinal stack occurs. The Transverse Zone overlies a pre-existing fault (Loch Assynt Fault), oriented at small angles to the thrust transport direction. Piercing-point analysis shows this fault records prethrusting as well as syn- to post thrusting displacement. The pre-thrusting faulting caused a step in the basement and cover strata of about $100 \mathrm{~m}$. The resultant Transverse Zone is much larger in scale than the original step; this enhancement was probably caused by oblique, transpressional thrust stacking. The study shows that relatively small disturbances in the pre-thrusting template can lead to significant lateral variations in thrust geometry. A number of shear zones with similar trends are related to other lateral variations along the length of the Moine Thrust Belt.

\section{References}

Allison, I., May, F. \& Strachan, R. 1988. An excursion guide to the Moine geology of the Scottish Highlands, Scottish Academic Press.

Alsop, G. I. \& Holdsworth, R. E. 2004. Shear zone folds; records of flow perturbation or structural inheritance? In: Alsop, G. I., Holdsworth, R. E., McCaffrey, K. J. W. \& Hand, M. (Eds). Flow processes in faults and shear zones. Geological Society Special Publications, 224, 177-199.

Armstrong, H., Raine, R. \& Smith, M. P. 2006. Iapetus - From coast to coast. ICOS 2006 post-conference field trip, University of Birmingham, Birmingham.

Attfield, P. 1987. The structural history of the Canisp Shear Zone. In: Park, R. G. \& Tarney, J. (Eds). Evolution of the Lewisian and comparable Precambrian high grade terrains. Geological Society Special Publication, 27, 165-173.

Bailey, E. B. 1935. The Glencoul Nappe and the Assynt Culmination. Geological Magazine, 72, 151-165.

Barr, D., Holdsworth, R. E. \& Roberts, A. M. 1986. Caledonian ductile thrusting in a Precambrian metamorphic complex: the Moine of NW Scotland. Bulletin of the Geological Society of America, 97, 754-764.

Beach, A., Coward, M. P. \& Graham, R. H. 1974. An interpretation of the structural evolution of the Laxford front. Scottish Journal of Geology, 9, 297-308.

Beacom, L. E., Holdsworth, R. E., McCaffrey, K. J. W. \& Anderson, T. B. 2001. A quantitative study of the influence of pre-existing compositional and fabric heterogeneities upon fracture-zone development during basement reactivation. In: Holdsworth, R. E., Strachan, R. A., Macgloughlin, J. F. \& Knipe, R. J. (Eds). The nature and significance of fault zone weakening. Geological Society Special Publication, 186, 195-211.

Bégin, N. J. \& Spratt, D. A. 2002. Role of transverse faulting in along-strike termination of Limestone Mountain Culmination, Rocky Mountain thrust-and-fold belt, Alberta, Canada. Journal of Structural Geology, 24, 689-707.

British Geological Survey. 1999. Gairloch, Scotland Sheet 91 and 100, Solid and Drift Geology. 1:50 000. British Geological Survey, Keyworth, Nottingham.

British Geological Survey. 2002a. Point of Stoer, Scotland Sheet 107W, Solid and Drift Geology. 1:50 000. British Geological Survey, Keyworth, Nottingham.

British Geological Survey. 2002b. Loch Eriboll, Scotland Sheet 114W, Solid Geology. 1:50 000. British Geological Survey, Keyworth, Nottingham.

British Geological Survey. 2007. Assynt. Scotland Special Sheet. Bedrock. 1:50 000 Geology Series. British Geological Survey., Keyworth, Nottingham.

Butler, R. W. H. 1982. A structural analysis of the Moine Thrust Zone between Loch Eriboll and Foinaven, NW Scotland. Journal of Structural Geology, 4, 19-29.

Butler, R. W. H. 1984. Structural evolution of the Moine Thrust Belt between Loch More and Glendhu, Sutherland. Scottish Journal of Geology, 20, 161-179.

Butler, R. W. H., Matthews, S. J. \& Morgan, R. K. 2007. Structural evolution of the Achnashellach Culmination, southern Moine thrust belt; testing the duplex model. In: Ries, A. C., Butler, R. W. H. \& Graham, R. H. (Eds). Deformation of the continental crust; the legacy of Mike Coward. Geological Society Special Publications, 272, 103-120. 
Calassou, S., Larroque, C. \& Malavieille, J. 1993. Transfer zones of deformation in thrust wedges; an experimental study. Tectonophysics, 221, 325-344.

Callaway, C. 1883. The age of the newer gneissoic rocks of the northern Highlands. Quarterly Journal of the Geological Society of London, 39, 355-422.

Cartwright, I. \& Barnicoat, A. C. 1987. Petrology of Scourian supracrustal rocks and orthogneisses from Stoer, NW Scotland: implications for the geological evolution of the Lewisian complex. In: Park, R. G. \& Tarney, J. (Eds). Evolution of the Lewisian and comparable Precambrian high grade terrains. Geological Society Special Publication, 27, 93-107.

Christie, J. M. 1963. The Moine thrust zone in the Assynt region, Northwest Scotland. University of California Publications in Geological Sciences, 40, 345-440.

Cobbold, P. R. \& Quinquis, H. 1980. Development of sheath folds in shear regimes. Journal of Structural Geology, 2, 119-126.

Coward, M. P. 1982. Surge zones in the Moine Thrust Zone of NW Scotland. Journal of Structural Geology, 4, 247-256.

Coward, M. P. 1983. The thrust and shear zones of the Moine Thrust Zone of NW Scotland. Journal of the Geological Society of London, 140, 795-811.

Coward, M. P. 1984. The strain and textural history of thin-skinned tectonic zones: examples from the Assynt region of the Moine thrust zone. Journal of Structural Geology, 6, 89-99.

Coward, M. P. 1985. The thrust structures of southern Assynt, Moine thrust zone. Geological Magazine, 122, 596-607.

Coward, M. P. \& Kim, J. H. 1981. Strain within thrust sheets. In: McClay, K. R. \& Price, N. J. (Eds). Thrust and Nappe Tectonics. Geological Society Special Publication, 9, London, 275-292.

Coward, M. P. \& Park, R. G. 1987. The role of mid-crustal shear zones in the Early Proterozoic evolution of the Lewisian. In: Park, R. G. \& Tarney, J. (Eds). Evolution of the Lewisian and Comparable Precambrian High Grade Terrains. Geological Society Special Publication, 27, 127-138.

Coward, M. P. \& Potts, G. J. 1983. Complex strain patterns developed at the frontal and lateral tips to shear zones and thrust zones. Journal of Structural geology, 5, 383-399.

Coward, M. P. \& Potts, G. J. 1985. Fold nappes: examples from the Moine Thrust Zone. In: Gee, D. G. \& Sturt, B. A. (Eds). The Caledonide Orogen - Scandinavia and related areas. Wiley, 1147-1158.

Dallmeyer, R. D., Strachan, R. A., Rogers, G., Watt, G. R. \& Friend, C. R. L. 2001. Dating deformation and cooling in the Caledonian thrust nappes of north Sutherland, Scotland: insights from 40Ar/39Ar and Rb-Sr chronology. Journal of the Geological Society, 158, 501-512.

Dubey, A. K. 1997. Simultaneous development of noncylindrical folds, frontal ramps, and transfer faults in a compressional regime; experimental investigations of Himalayan examples. Tectonics, 16, 336346.

Elliott, D. \& Johnson, M. R. W. 1980. Structural evolution in the northern part of the Moine thrust belt, NW Scotland. Transactions of the Royal Society of Edinburgh: Earth Sciences, 71, 69-96.

Fermor, P. 1999. Aspects of the three-dimensional structure of the Alberta Foothills and Front Ranges. Geological Society of America Bulletin, 111, 317-346.

Freeman, S. R., Butler, R. W. H., Cliff, R. A. \& Rex, D. C. 1998. Direct dating of mylonite evolution; a multi-disciplinary geochronological study from the Moine thrust zone, NW Scotland. Journal of the Geological Society of London, 155, 745-758.

Geological Survey of Great Britain 1923. Geological map of the Assynt District Scotland, 1:63 360.

Goodenough, K. M., Park, R. G., Krabbendam, M., Myers, J., Wheeler, J., Loughlin, S., Crowley, Q., Kinny, P., L, F. C. R., Beach, A. \& Graham, R. H. 2009. The Laxford Shear Zone: an Archaean terrane boundary? In: Law, R., Butler, R. W. H., Strachan, R. A. \& Krabbendam, M. (Eds). Continental tectonics and mountain building: the legacy of Peach and Horne. Geological Society Special Publications. this volume

Goodenough, K. M., Young, B. N. \& Parsons, I. 2004. The minor intrusions of Assynt, NW Scotland: early development of magmatism along the Caledonian Front. Mineralogical Magazine, 68, 541-559.

Gorney, D., Escalona, A., Mann, P., Magnani, M. B., Levander, A., Christeson, G., Zelt, C. A., Schmitz, M., Clark, S., Guedez, M. C., Bezada, M., Arogunmati, Y., Aitken, T. \& Beardsley, A. 2007. Chronology of Cenozoic tectonic events in western Venezuela and the Leeward Antilles based on integration of offshore seismic reflection data and on-land geology. AAPG Bulletin, 91, 653-684. 
Halliday, A. N., Aftalion, M., Parsons, I., Dickin, A. P. \& Johnson, M. R. W. 1987. Syn-orogenic alkaline magmatism and its relationship to the Moine Thrust Zone and the thermal state of the lithosphere in NW Scotland. Journal of the Geological Society of London, 144, 611-618.

Hinsch, R., Krawczyk, C. M., Gaedicke, C., Giraudo, R. \& Demuro, D. 2002. Basement control on oblique thrust sheet evolution; seismic imaging of the active deformation front of the Central Andes in Bolivia. Tectonophysics, 355, 23-39.

Holdsworth, R. E., Strachan, R. A., Alsop, G. I., Grant, C. J. \& Wilson, R. W. 2006. Thrust sequences and the significance of low-angle, out-of-sequence faults in the northernmost Moine Nappe and Moine thrust zone, NW Scotland. Journal of the Geological Society of London, 163, 801-814.

Holdsworth, R. E., Alsop, G. I. \& Strachan, R. A. 2007. Tectonic stratigraphy and structural continuity of the northernmost Moine thrust zone and Moine Nappe, Scottish Caledonides. In: Ries, A. C., Butler, R. W. H. \& Graham, R. H. (Eds). Deformation of the continental crust; the legacy of Mike Coward. Geological Society Special Publications, 272, 121-142.

Kinny, P. D., Friend, C. R. L. \& Love, G. J. 2005. Proposal for a terrane-based nomenclature for the Lewisian Gneiss Complex of NW Scotland. Journal of the Geological Society of London, 162, 175-186.

Krabbendam, M. \& Leslie, A. G. 2004. Lateral ramps and thrust terminations: an example from the Moine Thrust Zone, NW Scotland. Journal of the Geological Society of London, 161, 551-554.

Krabbendam, M., Prave, A. P. \& Cheer, D. 2008. A fluvial origin for the Neoproterozoic Morar Group, NW Scotland; implications for Torridon - Morar group correlation and the Grenville Orogen Foreland Basin. Journal of the Geological Society of London, 165, 379-394.

Lapworth, C. 1883. The Secret of the Highlands. Geological Magazine, decade 2, 10, 120-128.

Lapworth, C. 1884. On the structure and metamorphism of the rocks of the Durness-Eriboll district. Proceedings of the Geologists' Association, 8, 438-442.

Laubscher, H. P. 1985. Large-scale, thin-skinned thrusting in the southern Alps; kinematic models. Geological Society of America Bulletin, 96, 710-718.

Leslie, A. G., Krabbendam, M., Kimbell, G. S. \& Strachan, R. A. 2009. The Oykel Transverse Zone: linking mullions, regional gravity, and large-scale lateral variations in ductile thrust architecture in the Moine Nappe, Northern Highlands, Scotland. In: Law, R., Butler, R. W. H., Strachan, R. A. \& Krabbendam, M. (Eds). Continental tectonics and mountain building: the legacy of Peach and Horne. Geological Society Special Publications. this volume

McClay, K. R. 1992. Thrust tectonics Chapman and Hall, London.

McClay, K. R. 2004. Thrust tectonics and hydrocarbon systems. AAPG Memoir 82.

McClay, K. R. \& Coward, M. P. 1981. The Moine Thrust Zone: an overview. In: McClay, K. R. \& Price, N. J. (Eds). Thrust and Nappe Tectonics. Geological Society Special Publication, 9, London, 241260.

McDougal, J. W. \& Khan, S. H. 1990. Strike-slip faulting in a foreland fold-thrust belt; the Kalabagh Fault and western Salt Range, Pakistan. Tectonics, 9, 1061-1075.

McKie, T. 1990. Tidal and storm influenced sedimentation from a Cambrian transgressive passive margin sequence. Journal of the Geological Society of London, 147, 785-794.

McMechan, M. 2002 Structural geometry in the Carbon Creek area of the Rocky Mountain Fold and Thrust Belt, northeastern British Columbia. Bulletin of Canadian Petroleum Geology, 50, 407-418.

Mitra, S. 1988. Three-dimensional geometry and kinematic evolution of the Pine Mountain thrust system, Southern Appalachians. Geological Society of America Bulletin, 100, 72-95.

Mon, R., Monaldi, C. R. \& Salfity, J. A. 2005. Curved structures and interference fold patterns associated with lateral ramps in the Eastern Cordillera, Central Andes of Argentina. Tectonophysics, 399, 173-179.

Murchison, R. I. 1867. Siluria, J Murray, London.

Nichol, J. 1857. On the red sandstone and conglomerate, and the superposed quartz rocks, limerstones and gneiss on the north-west coast of Scotland. Quarterly Journal of the Geological Society of London, 13, 17-39.

Oldroyd, D. R. 1990. The Highlands Controversy: Constructing Geological Knowledge through Fieldwork in Nineteenth-Century Britain, University of Chicago Press, Chicago. 
Pană, D. I. 2003. Precambrian Basement of the Western Canada Sedimentary Basin in Northern Alberta. . Alberta Geological Survey Earth Sciences Report 2002-02.

Park, R. G. 2002. The Lewisian geology of Gairloch, NW Scotland. Geological Society of London, Memoir 26.

Park, R. G., Stewart, A. D. \& Wright, D. T. 2002. The Hebridean terrane. In: Trewin, N. H. (Eds). The Geology of Scotland. Geological Society, London, 45-80.

Parsons, I. 1999. Late Ordovician to mid-Silurian alkaline intrusions of the North-west Highlands of Scotland. In: Stephenson, D., Bevins, R. E., Milward, D., Highton, A. J., Parsons, I., Stone, P. \& Wadsworth, W. J. (Eds). Caledonian Igneous rocks of Great Britain. Geological Conservation Review Series, 17 Chapman \& Hall, 345-393.

Paulsen, T. \& Marshak, S. 1998. Charleston transverse zone, Wasatch Mountains, Utah; structure of the Provo Salient's northern margin, Sevier fold-thrust belt. Geological Society of America Bulletin, 110, 512-522.

Paulsen, T. \& Marshak, S. 1999. Origin of the Uinta Recess, Sevier fold-thrust belt, Utah; influence of basin architecture on fold-thrust belt geometry. Tectonophysics, 312, 203-216.

Peach, B. N., Horne, J., Gunn, W., Clough, C. T., Hinxman, L. W. \& Teall, J. J. H. 1907. The geological structure of the North-West Highlands of Scotland, 668, 52 plates.

Price, R. A. 1981. The Cordilleran foreland thrust and fold belt in the southern Canadian Rocky Mountains. In: McClay, K. R. \& Price, N. J. (Eds). Thrust and Nappe Tectonics. Geological Society Special Publication, 9, London, 427-448.

Prigmore, J. K. \& Rushton, A. W. A. 1999. Scotland: Cambrian and Ordovician of the Hebridean Terrane. In: Rushton, A. W. A., Owen, A. W., Owens, R. M. \& Prigmore, J. K. (Eds). British Cambrian to Ordovician Stratigraphy. Geological Conservation Review Series, 18 Chapman \& Hall, 295-315.

Ramsay, J. G. 1997. The geometry of a deformed unconformity in the Caledonides of NW Scotland. In: Sengupta, S. (Eds). Evolution of geological structures in micro- to macro-scales. Chapman \& Hall, London, 445-472.

Ross, G. M., Parrish, R. R., Villeneuve, M. E. \& Bowring, S. A. 1991. Geophysics and geochronology of the crystalline basement of the Alberta Basin, western Canada. Canadian Journal of Earth Sciences, 28, 512-522.

Sabine, P. A. 1953. The petrography and geological significance of the post-Cambrian minor intrusions of Assynt and the adjoining districts of north-west Scotland. Quarterly Journal of the Geological Society of London, 109, 137-171.

Schreurs, G., Haenni, R. \& Vock, P. 2001. Four-dimensional analysis of analog models; experiments on transfer zones in fold and thrust belts. In: Koyi, H. A. \& Mancktelow, N. S. (Eds). Tectonic modeling; a volume in honor of Hans Ramberg. Geological Society of America Memoir, 193, 179-190.

Soto, R., Casas, A. M., Storti, F. \& Faccenna, C. 2002. Role of lateral thickness variations on the development of oblique structures at the western end of the South Pyrenean central unit. Tectonophysics, 350, 215-235.

Stewart, A. D. 2002. The Later Proterozoic Torridonian Rocks of Scotland: their Sedimentology, Geochemistry and Origin. Geological Society Memoir 24.

Strachan, R., Smith, M., Harris, A. L. \& Fettes, D. J. 2002. The Northern Highland and Grampian terranes. In: Trewin, N. H. (Eds). The Geology of Scotland. The Geological Society, London, 81-147.

Thomas, W. A. 1990. Controls on locations of transverse zones in thrust belts. Eclogae Geologicae Helvetiae, 83, 727-744.

Thomas, W. A. \& Bayona, G. 2002. Palinspastic restoration of the Anniston transverse zone in the Appalachian thrust belt, Alabama. Journal of Structural Geology, 24, 797-826.

Tull, J. F. \& Holm, C. S. 2005. Structural evolution of a major Appalachian salient-recess junction; consequences of oblique collisional convergence across a continental margin transform fault Geological Society of America Bulletin, 117, 482-499.

Van Breemen, O., Aftalion, M. \& Johnson, M. R. 1979. Age of the Loch Borrolan complex, Assynt and late movements along the Moine Thrust Zone. Journal of the Geological Society of London, 16, 489-495. 
Wheeler, J. 2007. A major high-strain zone in the Lewisian Complex in the Loch Torridon area, NW Scotland; insights into deep crustal deformation In: Ries, A. C., Butler, R. W. H. \& Graham, R. H. (Eds). Deformation of the continental crust; the legacy of Mike Coward. Geological Society Special Publication, 272, 27-45.

Wheeler, J., Windley, B. F. \& Davies, F. B. 1987. Internal evolution of the major Precambrian shear belt at Torridon, NW Scotland. In: Park, R. G. \& Tarney, J. (Eds). Evolution of the Lewisian and comparable Precambrian high grade terrains. Geological Society Special Publication, 27, $217-$ 233.

Wilkinson, P., Soper, N. J. \& Bell, A. N. 1975. Skolithus pipes as strain markers in mylonites. Tectonophysics, 28, 143-157.

Wright, D. T. \& Knight, I. 1995. A revised chronostratigraphy for the lower Durness group. Scottish Journal of Geology, 31, 11-22. 


\section{Figure Captions}

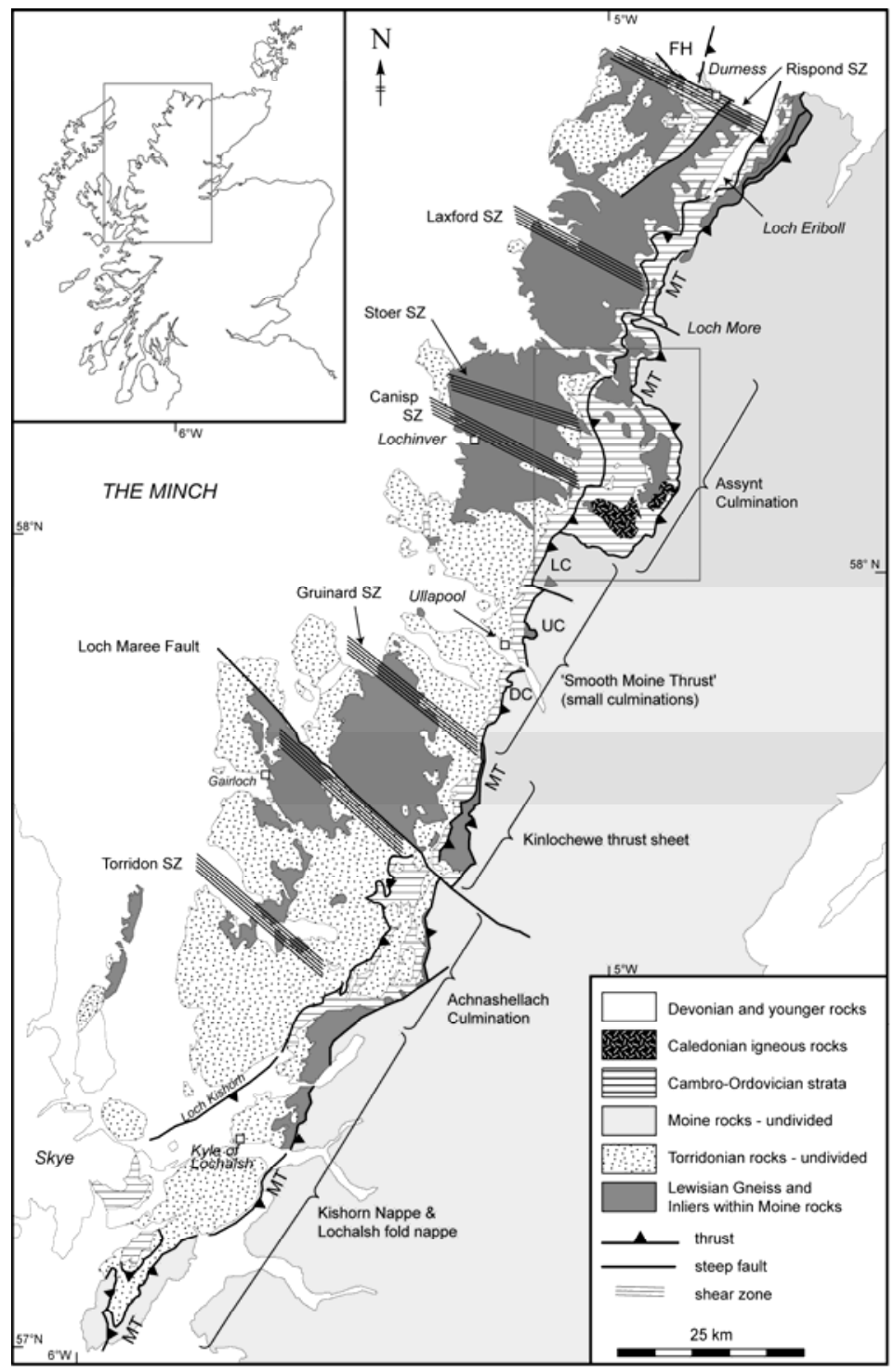

Figure 1. Geological map of the Moine Thrust Belt, North West Highlands. MT = Moine Thrust, LC $=$ Langwell Culmination; $\mathrm{UC}=$ Ullapool Culmination; $\mathrm{DC}=$ Dundonell Culmination; $\mathrm{FH}=$ Faraid Head. No details east of Moine Thrust shown. Inset shows position of Figure 2. 


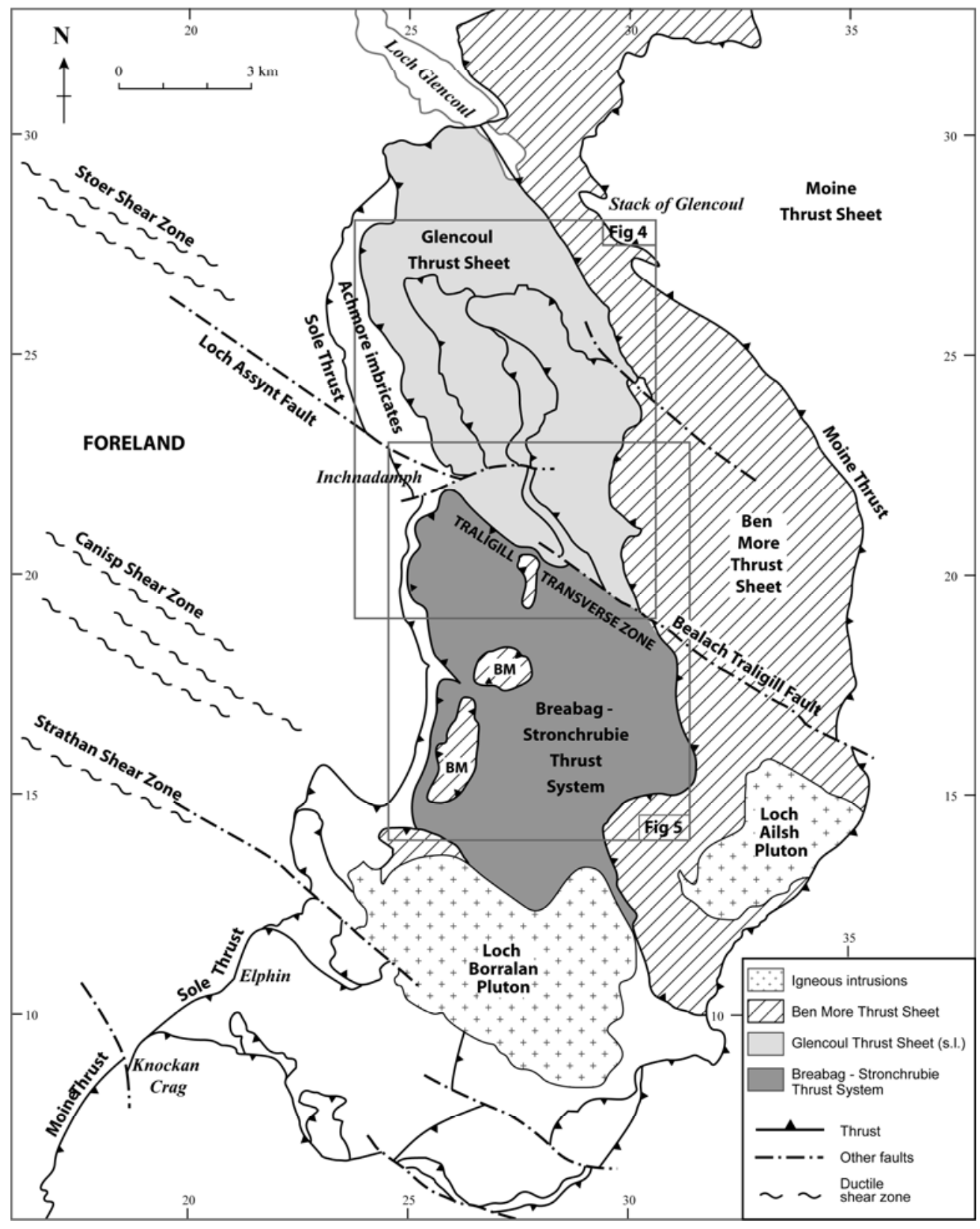

Figure 2. Simplified structure of the Assynt Culmination, showing main thrust sheets and Caledonian igneous intrusions. $\mathrm{BM}=$ klippen of the Ben More Thrust Sheet. Location of Figures 4 and 5 indicated. See also British Geological Survey (2007). 


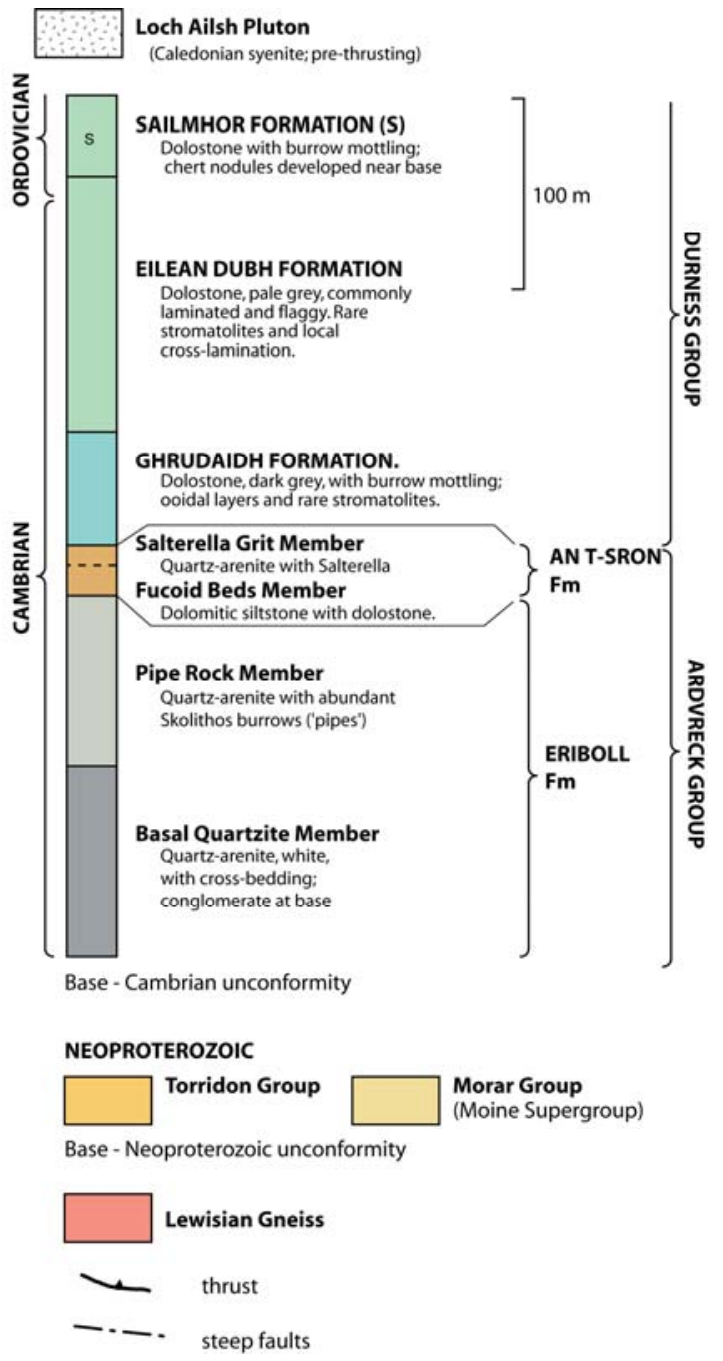

Figure 3. Generalised vertical section for Assynt, also to be used as key for Figures 4, 5, 6, 7. Scale bar applicable to Cambro-Ordovician rocks only. See also Park et al. (2002); British Geological Survey (2007). 


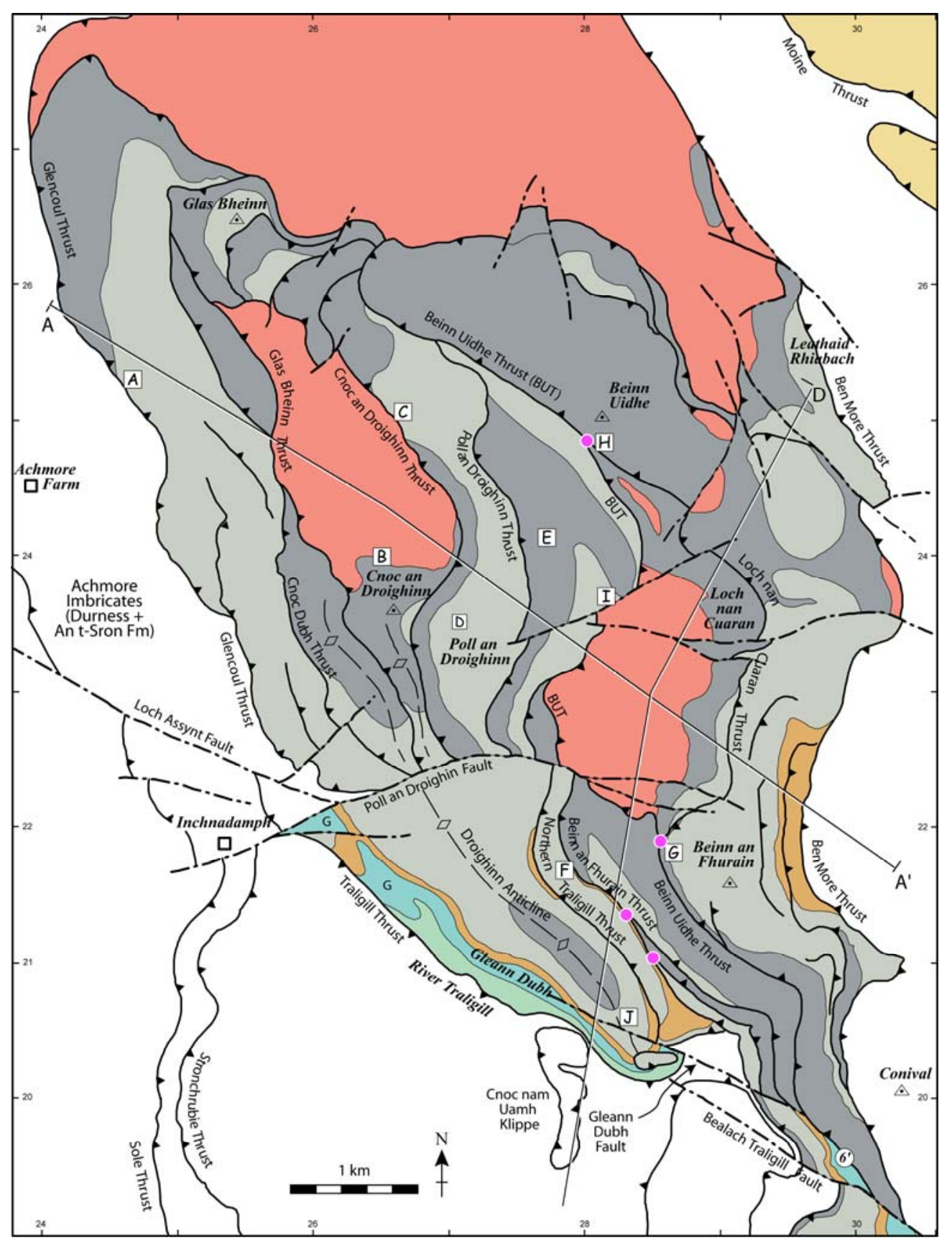

Figure 4. Geological map of the Droighinn area, northern part of the Assynt Culmination. Detailed geology in Ben More Thrust Sheet, Stronchrubbie-Breabag System and Achmore imbricates not shown. Position of cross-section line A-A' and D-D' (see Figure 6) is indicated. Grid ticks refer to NC square of the British National Grid. Points $\mathbf{A}$ to $\mathbf{J}$ are explained in the text. For key see Figure 3; purple points are selected branching points. After British Geological Survey (2007). 

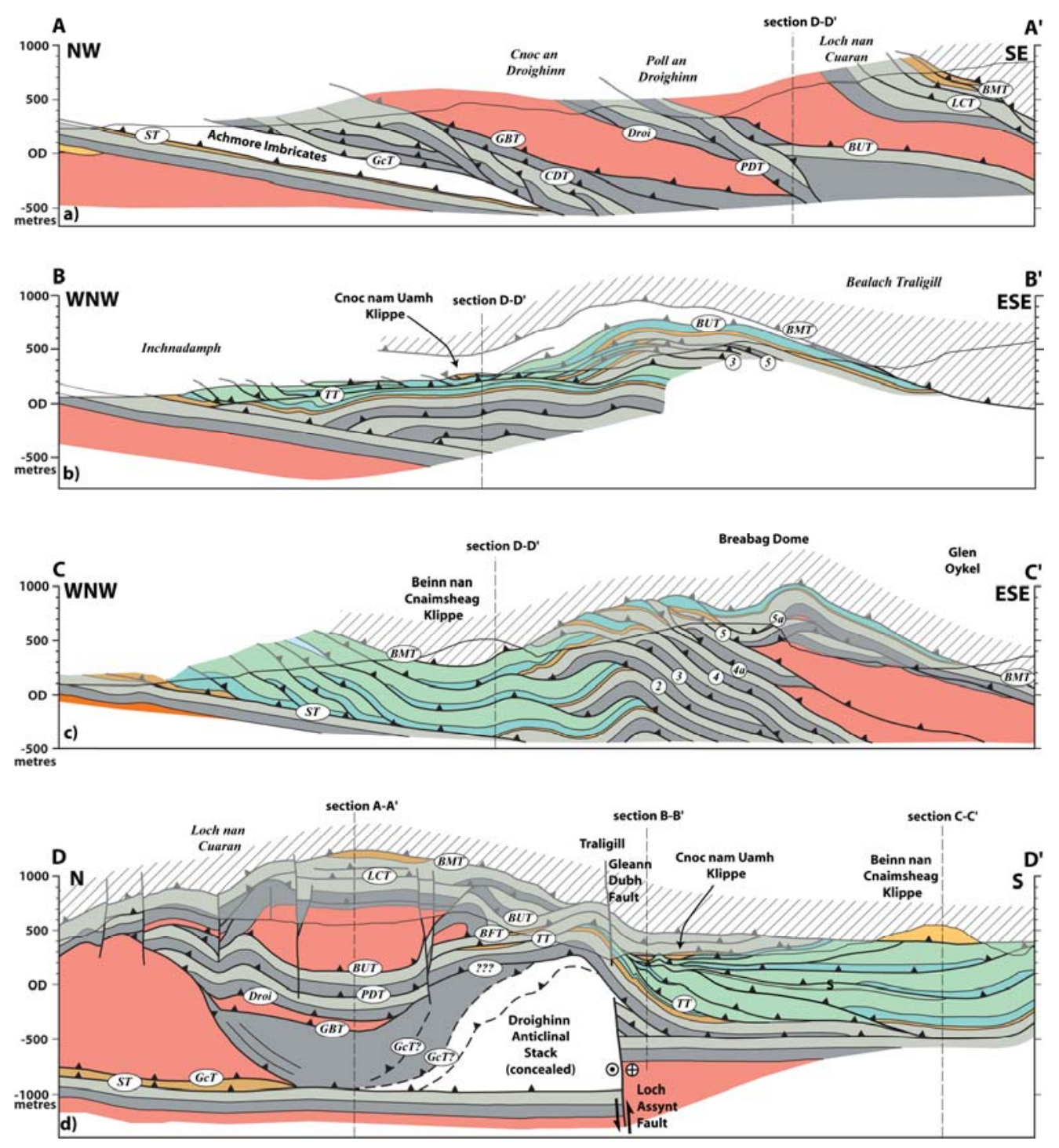

Figure 5. Geological map of the Stronchrubbie-Breabag System area, central part of the Assynt Culmination. Thrusts are numbered. Detailed geology in Ben More Thrust Sheet is not shown. Position of cross-section lines B-B', C-C' and D-D' (see Figure 6) is indicated. Grid ticks refer to NC square of the British National Grid. Points $\mathrm{P}$ to $\mathrm{X}$ are explained in the text. For key see Figure 3. $\mathrm{Tr}=$ Traligill Thrust; $\mathrm{br}=$ breaching thrust. After British Geological Survey (2007). 


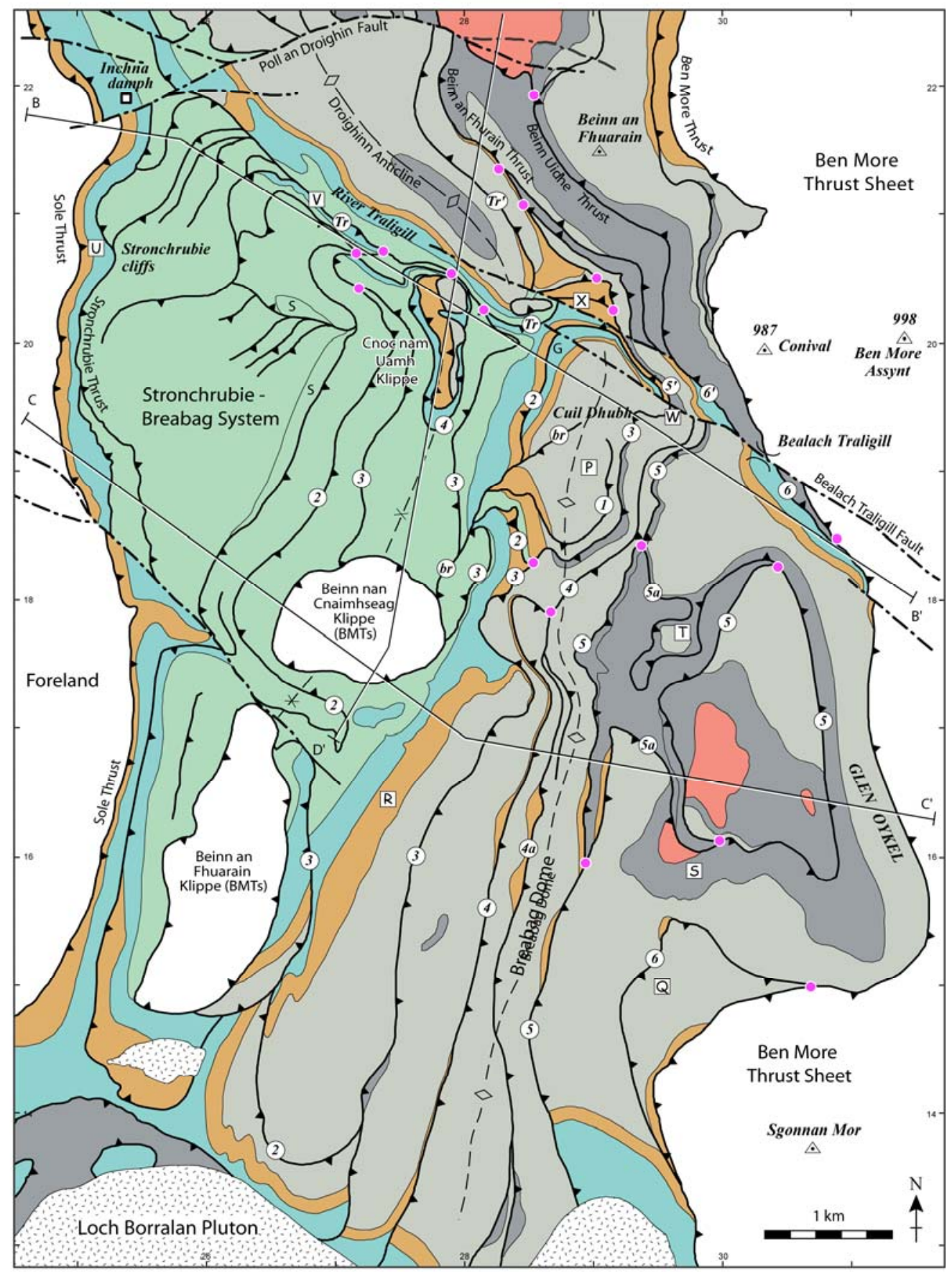

Figure 6. Figure 6. Cross-sections showing thrust architecture in Assynt Culmination. Locations of section lines are indicated on Figures 4 and 5. For key see Figure 3. Ben More Thrust sheet is hatched. No vertical exaggeration. See also British Geological Survey (2007). BFT $=$ Beinn an Fhurain Thrust, BMT = Ben More Thrust, $\mathrm{BUT}=$ Beinn Uidhe Thrust, $\mathrm{CDT}=$ Cnoc Dubh Thrust, Droi $=\mathrm{Cnoc}$ an Droighinn Thrust, GBT $=$ Glas Bheinn Thrust, GcT $=$ Glencoul Thrust, $\mathrm{LCT}=$ Loch nan Cuaran Thrust, PDT $=$ Poll an Droighinn Thrust, TT $=$ Traligill Thrust, $\mathrm{ST}=$ Sole Thrust

a) Cross-section across Droighinn area, north of Traligill Transverse Zone.

b) Cross-section across Breabag-Stronchrubbie system, just south of Traligill Transverse Zone.

c) Cross-section across Breabag-Stronchrubbie system, 2-3 km south of Traligill Transverse Zone.

d) North-south cross-section (normal to transport direction) across the Traligill Transverse Zone. 


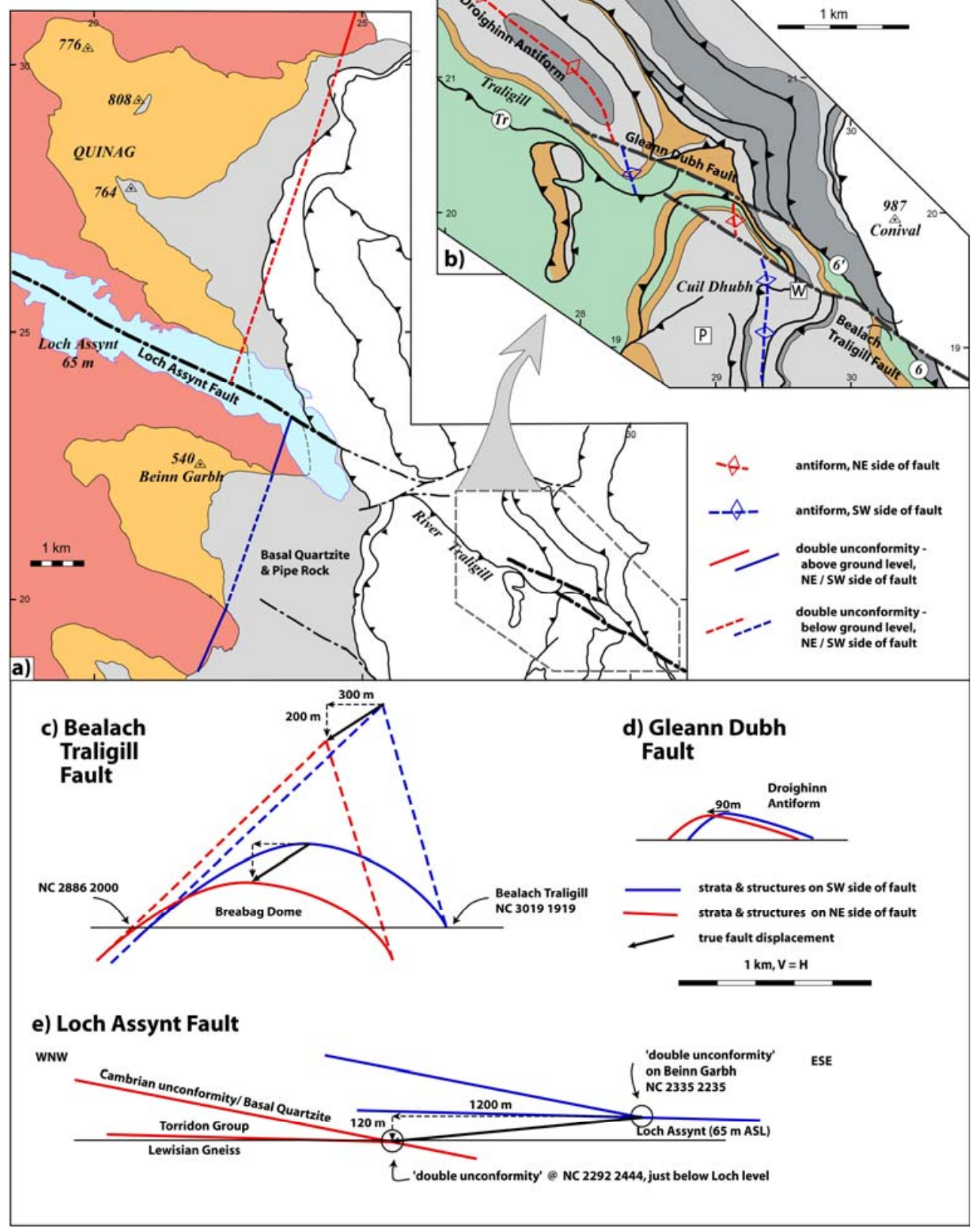

Figure 7. Piercing point analysis along the Traligill Tranverse Zone:

a) Overview map of the Foreland, showing position of 'Double Unconformity' abd the main cross-faults. b) Detail of upper Traligill, showing Droighinn Anticline and Breabag Dome displaced by Gleann Dubh and Bealach Traligill Fault.

c) Piercing point analysis of Gleann Dubh Fault.

d) Piercing point analysis of Bealach Traligill Fault.

e) Piercing point analysis of Loch Assynt Fault. 


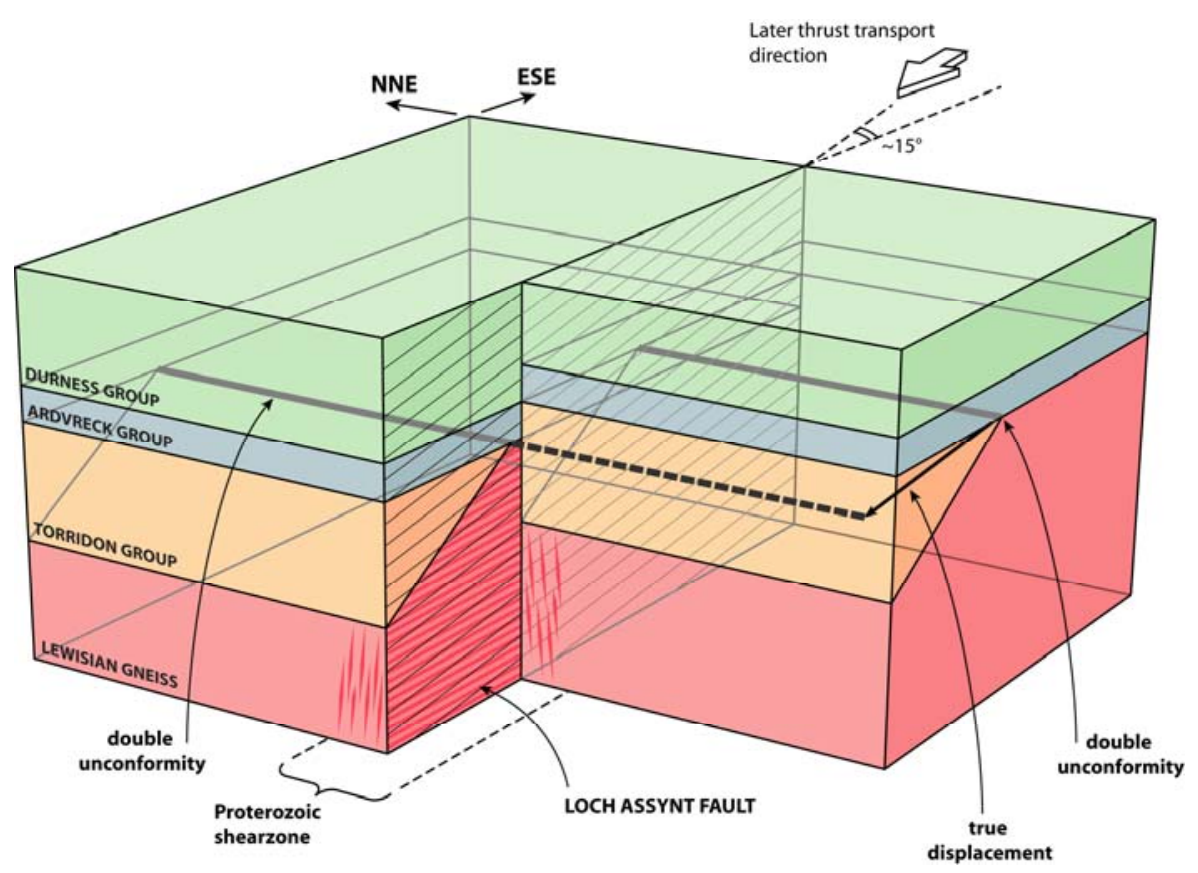

Figure 8: Schematic block diagram of the Traligill Transverse Zone, showing inferred architecture of basement and cover prior to thrusting. 

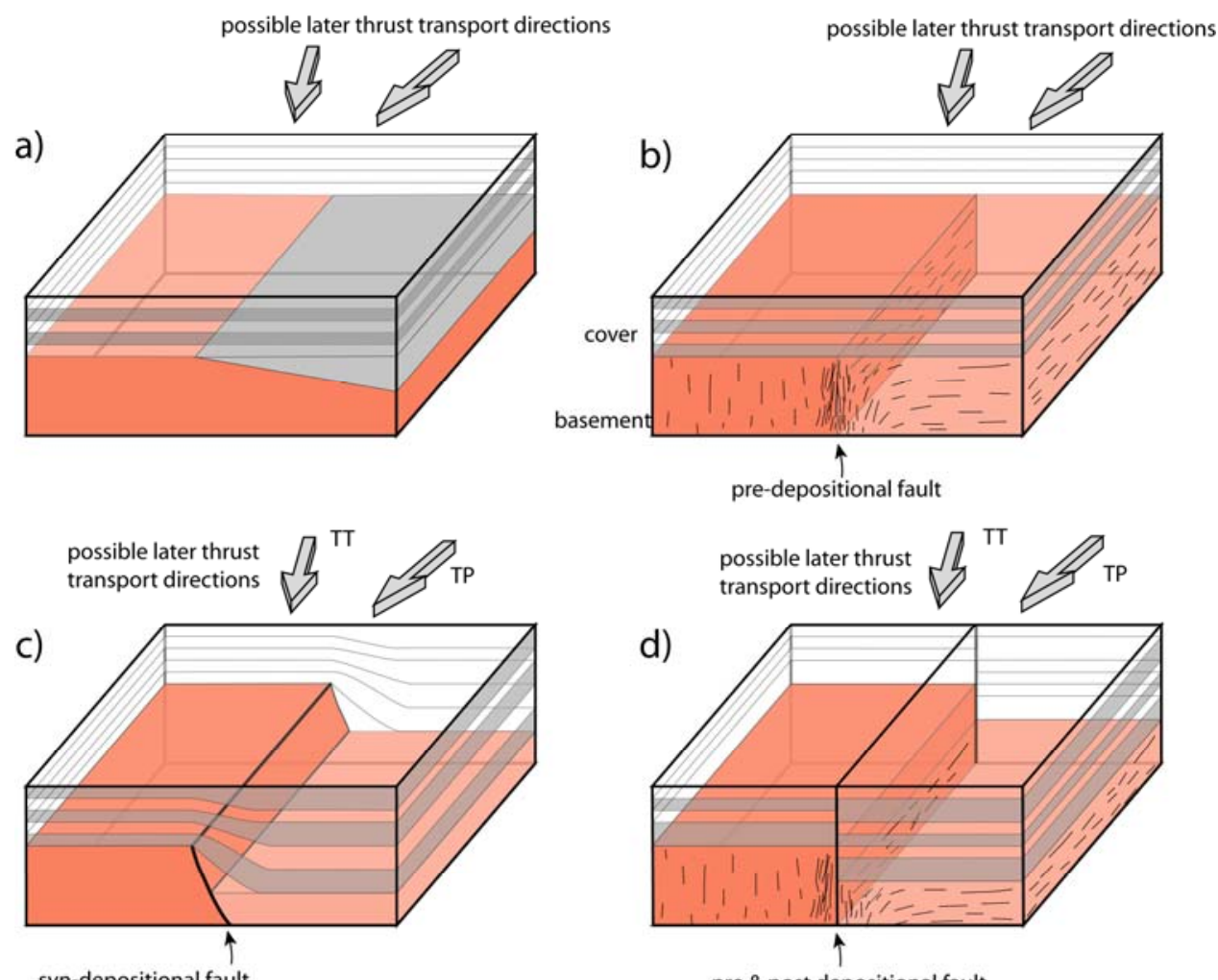

Figure 9: possible lateral variations in pre-thrusting templates:

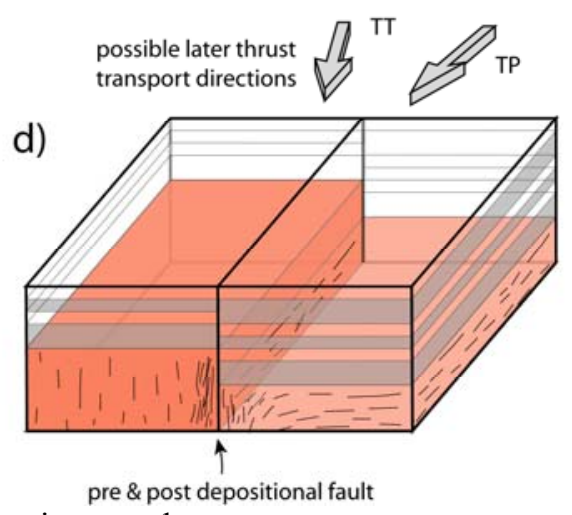

a) wedge of sediment;

b) pre-depositional fault in basement, not displacing cover strata;

c) syn-depositional fault in basement, active during deposition of cover strata;

d) pre \& post -depositional fault in basement displacing cover strata after deposition.

Note that different angles between the feature and the subsequent thrust transport direction (arrows) can lead to local transpression (TP) or transtension (TT); see text for discussion. 